depoimentos 


\title{
"não é impunemente que se entra para a família meneses"
}

\author{
O prazer do texto é esse momento em que \\ meu corpo vai seguir suas próprias ideias - \\ pois meu corpo não tem as mesmas ideias que eu.
}

Roland Barthes

... Durante a etapa de feitura desta edição da Opiniães, nós, os editores, sentimos a necessidade de criar uma seção que complementasse o trabalho analítico dos trabalhos que compõem o dossiê temático. Os artigos científicos representam um embate teórico com a Crônica da casa assassinada, em que cada pesquisador precisa obedecer às regras da escrita e da pesquisa acadêmica, o que significa ceder o espaço das impressões de leitura para o estudo analítico do texto. Nesta seção ocorre o caminho inverso: 21 pessoas foram convidadas a produzir um breve relato contando sua experiência singular de leitura da Crônica, a refletir sobre como o romance impactou nas suas visões de mundo, nas suas trajetórias pessoais. Não procure aqui, caro leitor, o relato frio da objetividade. O que há nesta seção é uma profusão de vozes com dicções distintas; quem vem agora a primeiro plano é o leitor, com sua escrita feita de impressões, de sentimentos confusos, de arrebatamento e de desafio diante do texto literário.

... Os depoimentos são acompanhados de um rico material iconográfico, alguns ainda inéditos, outros mais raros, que só o leitor especializado normalmente tem acesso. Alinhavando fotografias, desenhos e pinturas de Lúcio com os depoimentos, selecionamos alguns trechos da Crônica da casa assassinada, espalhados aqui e ali para que o leitor relembre algumas passagens (e para atiçar a vontade de quem ainda não adentrou a Chácara dos Meneses).

... A leitura da obra-prima de Lúcio Cardoso não é uma tarefa fácil. Exige mover-se dentro de uma atmosfera densa, adivinhar os sussurros por trás das portas, percorrer sorrateiro a casa, o jardim e o pavilhão. Pela ousadia de adentrar a Chácara e perscrutar os segredos da excêntrica família mineira o leitor certamente pagará um preço: os personagens hão de lhe fazer companhia pela vida afora, e não será uma tarefa fácil esquecer que não é impunemente que se entra para a família Meneses.

Editoras e Editores da Opiniães n. 17

Ana Maria Amorim Correia, Eduardo Marinho da Silva, Érica Ignácio da Costa, Frederico van Erven Cabala, Livia Azevedo Lima 

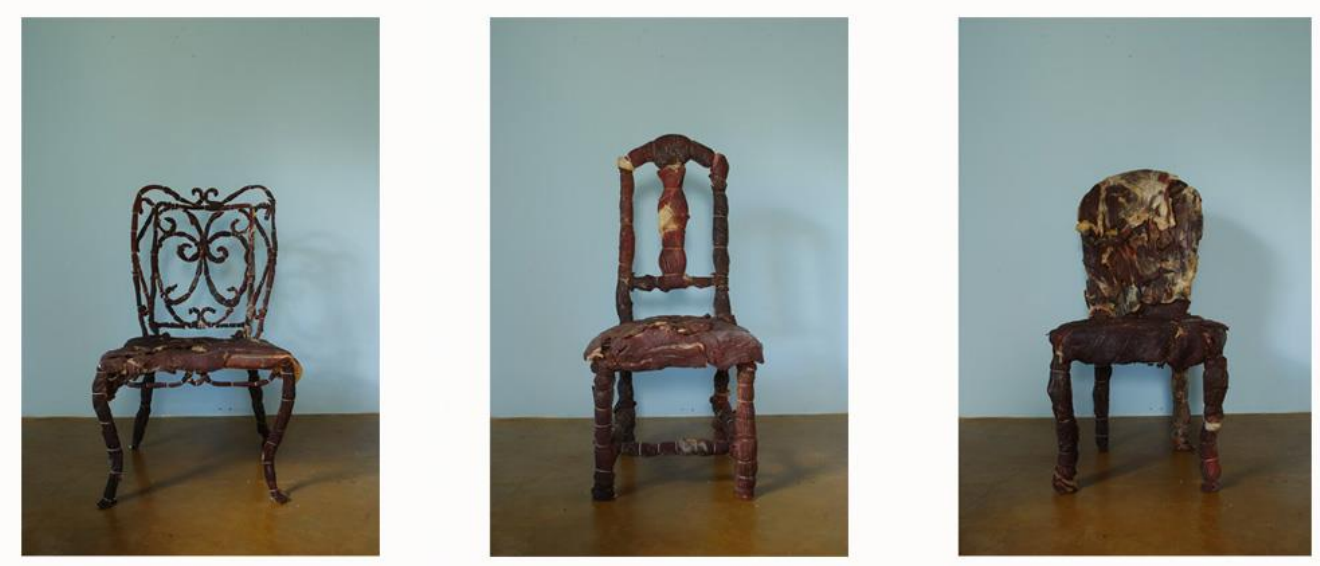

Adriana Varejão (1964-). Elegia mineira (tríptico). 3 fotos de 25 x 16,6 cm cada (edição de 10 + 3 P.A.), 2007.

Fotografia de Vicente de Mello.

Acervo Ateliê Adriana Varejão 
"Gostaria de me perguntar alguma coisa?", insinuei. Calado, vi que fazia um esforço para concentrar o pensamento. Dir-se-ia que rebuscava no mais íntimo de suas cogitações, ou que sondava a maneira exata de me dizer o que pretendia. Continuou: "Por exemplo..." E rompendo todas as amarras, exclamou de súbito, numa voz firme e baixa: "Padre, o que é o inferno?" Não, evidentemente não era aquela a pergunta que eu esperava, e fiquei calado por alguns momentos, olhando a varanda e o sol que batia sobre os ladrilhos. E como se fosse inspirado por uma força superior a mim, veio-me uma enorme vontade de responder, apontando com um simples gesto: " $O$ inferno é isto, esta casa, esta varanda, este sol que uniformiza tudo." Contive-me, no entanto, e volvi a cabeça para ele: "Ah, filho. O inferno é por sua essência a mais mutável das coisas. Em última análise, é a representação de todas as paixões dos homens." Ele pareceu não compreender logo e repetiu baixinho: "Paixões?" Fiz um gesto afirmativo com a cabeça: "Paixões, tendências profundas. O repouso, por exemplo." E ao dizer isto, senti que possivelmente de um modo um pouco arbitrário havia nomeado aquela casa, a varanda e o próprio brilho do sol.

Segunda narração de Padre Justino Crônica da casa assassinada. Lúcio Cardoso 


\section{milton hatoum}

Li Crônica da casa assassinada em meados da década de 1970, e o reli na Espanha uns anos depois, quando esboçava meu primeiro livro. No título do romance de Lúcio Cardoso, a alusão ao tempo, ao espaço e à morte apontam para alguns dos temas fundamentais da ficção e, em particular, da Crônica da casa assassinada.

A passagem do tempo, a decadência moral e social da família Meneses, a sondagem psicológica de personagens fortes e convincentes, a degradação da casa e seus elementos, a linguagem densa e vigorosa, tudo me fascinou nessa obraprima, em que a poética da destruição e das ruínas parece ser um dos vetores.

Na Crônica a lei divina é, de fato, “a da tempestade, e não a da calma”. Lúcio Cardoso armou uma estrutura fragmentária composta de cartas, diários e relatos de memória para evocar tempestuosas relações familiares, que se desenvolvem num complexo jogo temporal.

O incesto, o ciúme, a traição, o destino como fatalidade são temas que remontam às origens da literatura, mas foram assimilados e (re)interpretados pelo romance moderno. Vários estudos críticos analisaram os pontos de contato entre a Crônica e as obras de Faulkner e Dostoiévski. Penso que esses estudos comparativos são plausíveis. Em Absalão, Absalão! - um dos grandes romances de Faulkner -, o forasteiro Charles Bom é uma personagem trágica, que desestabiliza e leva à loucura a família do patriarca Sutpen. Na Crônica, a personagem Nina cumpre esse papel trágico. Vinda de fora, ela abala e desagrega a família Meneses, precipitando sua decadência, até a destruição.

Em graus variados, escritores são influenciados pelas obras de seus antecessores. Essa influência pode ser difusa, inconsciente, ou explicitamente declarada, em prefácios ou na própria obra de ficção.

Milton Hatoum é autor de romances como Relato de um Certo Oriente (1989, vencedor do Prêmio Jabuti), Dois irmãos (2000, vencedor do Prêmio Jabuti e traduzido para doze idiomas, além de ter recebido adaptações para televisão, teatro e quadrinhos) e Cinzas do Norte (2005, vencedor do Prêmio Jabuti, Bravo!, APCA e Portugal Telecom). Publicou recentemente os romances $A$ noite da espera (2017) e Pontos de fuga (2019), da trilogia $O$ lugar mais sombrio. 


\section{opiniães}

Desde a primeira leitura da Crônica, intuí que esse romance seria uma das minhas fontes literárias. No Pontos de fuga aparecem romances, peças de teatro e poemas que exerceram certo fascínio em algumas personagens. Não por acaso, Crônica da casa assassinada é citada pelo personagem Ox. E não poderia negar alguns traços da Crônica nos romances Relato de um certo Oriente e Dois irmãos, em que são centrais o drama familiar e o efeito devastador do tempo nas personagens, nos objetos e no espaço da casa que, aos poucos e inexoravelmente, se desfaz. 


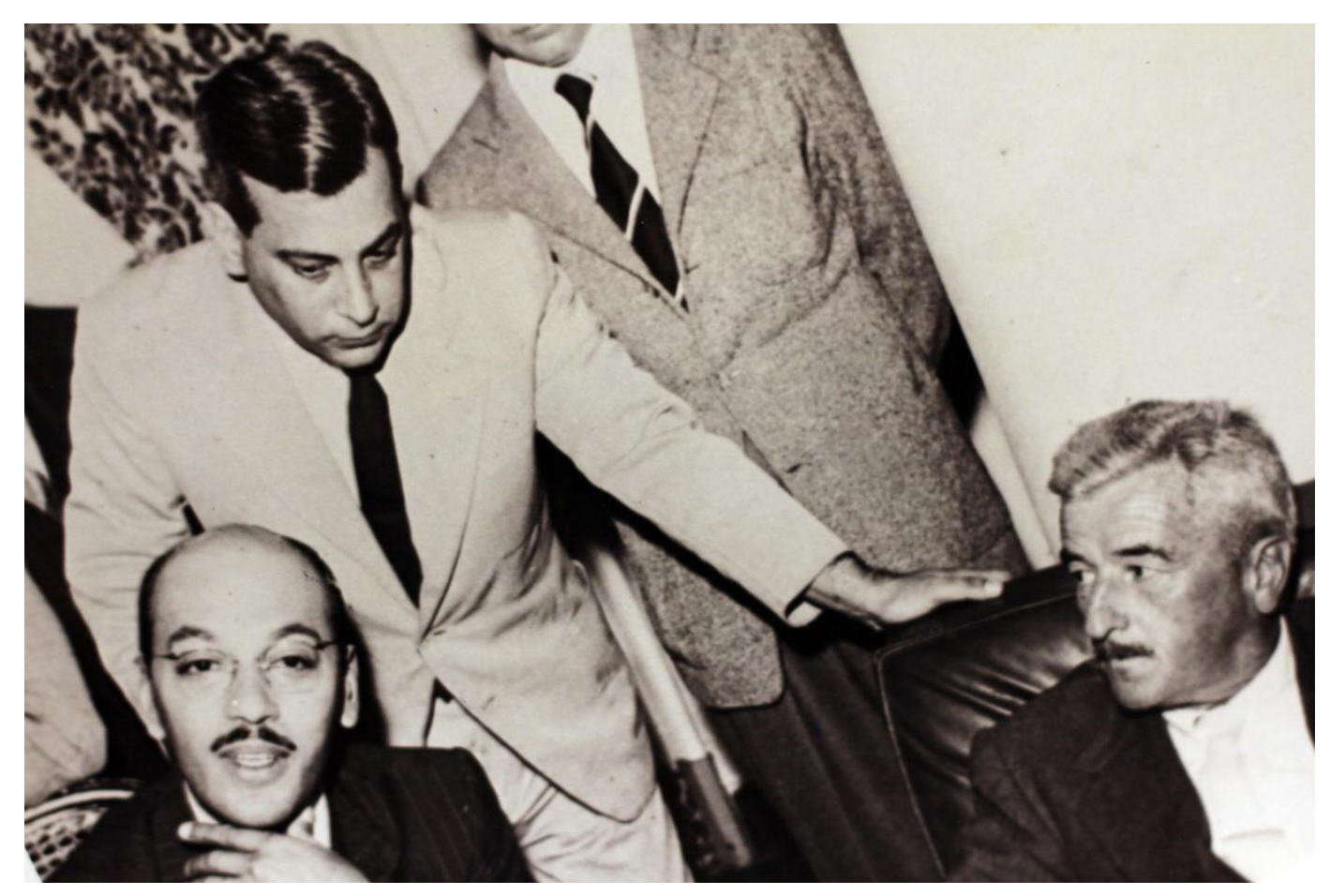

Lúcio Cardoso e William Faulkner (à direita) (1954). Acervo Luiz Carlos Lacerda 


\section{andré seffrin}

\section{LÚCIO, OCTAVIO, CRÔNICA DA CASA ASSASSINADA \\ E OUTROS EXTRAVIOS DA MEMÓRIA}

Lúcio Cardoso e Octavio de Faria, meus estranhos próximos. Caminham ambos, ontem como hoje, ao meu lado. Por limitações cronológicas e geográficas, nunca nos demos sequer um aperto de mão. E foi a minha convivência com Walmir Ayala que ampliou essa aproximação, crescente depois por meio, também, de Maria Helena Cardoso (Lelena) e Lourdes Cardoso Barros, duas irmãs de Lúcio, somadas às presenças de Marcos Konder Reis, Ione Saldanha, Alair Gomes, Maria Alice Barroso. Em seguida, agreguei outros conhecidos e amigos, e todos me deram intensas e variadas notícias dos autores da Crônica da casa assassinada e da Tragédia burguesa. Antônio Carlos Villaça, Foed Castro Chamma, Júlio José de Oliveira, Maria Fernanda (Meirelles), Guadalupe Puig Bopp (a Lupe), Lêdo Ivo, Julie van Rogger, Rachel de Queiroz, Edla van Steen, Sábato Magaldi, Fausto Wolff, Roberto Burle Marx, Paulo César Saraceni, Luiz Carlos Lacerda (o Bigode). Com estes e aqueles, uns mais outros menos próximos, ampliou-se o meu cerco aos dois romancistas.

Logo idealizei um Lúcio multiplicado aos pedaços, muitos Lúcios em Lúcio personagem de si mesmo. Para Walmir, ele foi a "embriaguez que não termina”, o amigo ido mas sempre lembrado. Nesse mundo líquido, ouvi tantas vezes de Walmir que Lúcio, mesmo doente, não deixava de ir ao centro da cidade, comprar roupa, olhar rua, curtir sol, e que aquilo que mais desejou nos seus anos finais era voltar a escrever. Ainda ouço a voz de Walmir: "Incrivelmente diferentes, mas tão

André Seffrin é crítico literário, ensaísta e pesquisador independente. Escreveu mais de uma centena de apresentações, prefácios e posfácios para edições de autores brasileiros tais como Gregório de Matos, Manuel Antônio de Almeida, Raul Pompeia, Aluísio Azevedo, Castro Alves, Visconde de Taunay, José Américo de Almeida, Lúcio Cardoso, Carlos Drummond de Andrade, Rachel de Queiroz, Rubem Braga, Cecília Meireles, Nelson Rodrigues, Ferreira Gullar, Alberto da Costa e Silva, Ariano Suassuna e Carlos Heitor Cony, entre outros. Foi colaborador de Última Hora, Jornal do Brasil, Jornal da Tarde, O Globo, Manchete, Gazeta Mercantil, EntreLivros etc., e coordenou coleções de clássicos para diversas editoras. Autor de ensaios críticos e biográficos, alguns em edições de arte Uoaquim Tenreiro, Paulo Osorio Flores, Sérgio Rodrigues), organizou cerca de 30 antologias, e a mais recente é Poesia completa e prosa seleta, de Manuel Bandeira (Nova Aguilar, 2020). 
amigos. Octavio compenetrado no seu terno e gravata; Lúcio, quase sempre descalço, num à vontade sem limites".

No "templo cardosiano" da rua Alberto de Campos, em Ipanema, Lúcio foi sempre o Nonô, apelido de infância que se manteve em família. Após 1968, continuou naquele endereço, pulsando invisível entre paredes, móveis e louças da casa, no que restava de sua biblioteca e de suas imagens de santos, nos quadros, na música, nos cálices de vinho branco que Lelena nunca deixou faltar. "Entre vazios sótãos da casa assassinada" (como quis Drummond), o vulto dele, pequenenorme, circulava, até o fim: nas conversas, na alegria algo triste dos amigos que não deixavam de aparecer no apartamento térreo hoje extinto - em seu lugar ganhou os céus uma edificação moderna bem ao jeito de uma Ipanema elitizada e sem passado. Dizem que Nonô gostava da proximidade com a Lagoa Rodrigo de Freitas, extraviado que viveu por aquelas paisagens, no tormento sem fim de seus enredos e personagens.

Por volta de 1989, veio este convite de Amos Segala: "Escreva a respeito do que você viu e ouviu sobre ele, naquela casa ou fora dela". Sua intenção era acrescentar à edição crítica da Crônica, na Coleção Archivos, o depoimento de um jovem. Com as fatais limitações da tenra idade, dei o meu testemunho. Coordenado por Mario Carelli, o livro, no entanto, acabou por não contentar plenamente o idealizador da coleção. A edição se tornara, segundo Amos, uma espécie de hagiológio: "Nada desestabiliza a atmosfera laudatória em torno do autor, algo incompatível com edições críticas", disse-me ele. Em edição futura, gostaria de corrigir ao menos em parte essa distorção: “Além de uma visão mais crítica sobre a Crônica, quero um texto de Walmir. Arranje-me um texto dele”. Nesse último caso, repararia uma injustiça - por que motivo o poeta Walmir, então recémfalecido, não integrara a edição de Carelli? Providenciei logo o material solicitado e assim as próximas edições, de 1996 e 1997, ganharam nova ilustração de capa (um óleo de Lúcio pertencente à coleção de Walmir) e, no fechamento da fortuna crítica, os ensaios de Wilson Martins e Walmir Ayala (e é bom não ignorar que mais tarde Martins daria continuidade àquele raciocínio radical de 1959, quando, em 1973, voltou ao tema, tão empolgado ficou com a leitura da obra-prima de Maria Helena Cardoso, Vida-vida, que lhe possibilitou reforçar a ideia de uma trágica frustração em Lúcio).

Tempos. Retalhos de convivências. Num de nossos poucos encontros, ouvi de Wilson Martins: “Aquela história de Lúcio considerar Octavio o melhor 


\section{opiniães}

romancista brasileiro e de Octavio sempre repetir a dose em relação ao Lúcio era cansativa, a velha tradição de elogios mútuos nos jornais”. É. Vale explorar o tema, em parte cristalizado por Manuel Bandeira no poema "Os voluntários do Norte". Fica a sugestão, enquanto, de muito longe, ouço outra vez a voz de Walmir, ainda sobre a Crônica: "Talvez tenha faltado ao Lúcio um pouco mais de coragem para a confirmação do incesto". A essa altura, naquela voz pausada que era a sua, Marcos afirma sobre Octavio: “Atração é o melhor romance da Tragédia burguesa”. Será? Penso, logo duvido. E um sibilino Villaça retorna aos meus ouvidos com a confissão inesperada: "Em minhas pesquisas nos arquivos de José Olympio, descobri que Walmir foi quem montou a versão final da Crônica, pois na segunda metade da década de 50, Lúcio já andava muito disperso, sem paciência para lidar com aquele material”. Ora viva, Villaça, Walmir me sonegou a informação, certamente na tentativa de proteger Lúcio, uma vez mais, de seus inimigos e detratores. Devo-me, há trinta anos, uma visita ao arquivo do editor José Olympio e novo passeio aos fólios do romance na Fundação Casa de Rui Barbosa. Um dia, quem sabe, irei. E mais não revelo porque "a vida não dá tempo para a Vida" observação que não é minha, é de Mario Quintana, que nada tem a ver com minhas memórias de Lúcio e Octavio, mas de quem certa vez ganhei um aperto de mão.

Rio, dezembro, 2020. 


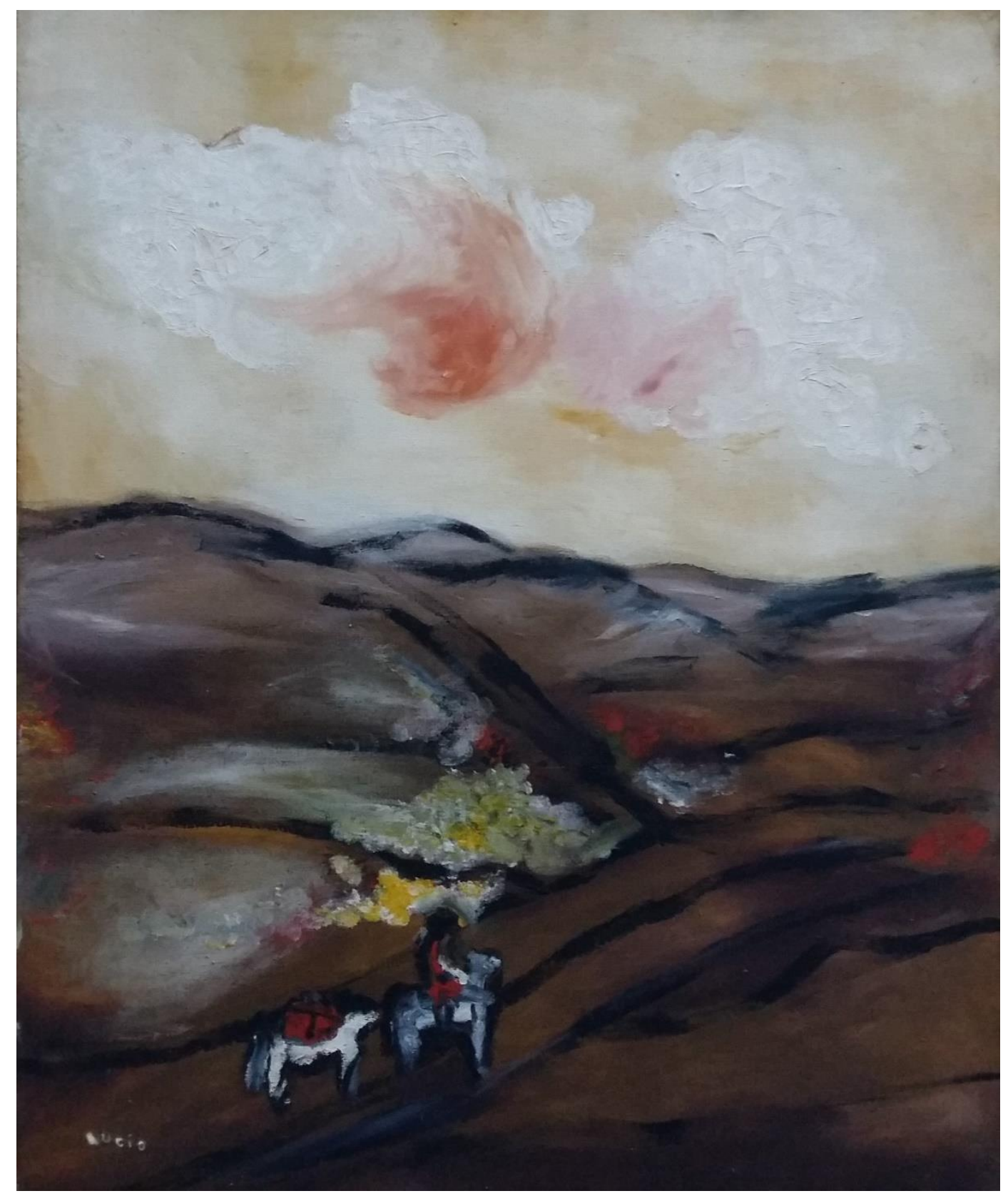

Lúcio Cardoso (1912-1968). Sem título [Montanhas de Minas], óleo sobre tela, 73 x $60 \mathrm{~cm}$. Assinada no c.i.e., s/d. Acervo Walmir Ayala 


\title{
opiniães
}

\section{amara moira}

\section{LEITURAS MONSTRUOSAS DA CRÔNICA}

No Desfazendo Gênero de 2015, realizado na UFBA (Salvador), foi quando escutei pela primeira vez (e da boca dela mesma) os conhecidos versos de Susy Shock, uma das artistas trans mais provocativas da cena cultural hispanoamericana:

Reivindico mi derecho a ser un monstruo

¿Que otros sean lo Normal!

Publicados em seu livro Poemario TransPirado (2011), estes versos rodaram o mundo, nomes como Judith Butler frequentemente os citando pelo alto poder contestatório que encapsulam. Qual a minha surpresa, dois anos depois, quando lendo pela primeira vez a Crônica da Casa Assassinada (1959), de Lúcio Cardoso, me deparo com uma ideia similar formulada por Timóteo, personagem que a governanta Betty considera um "estranho ser sem sexo":

\begin{abstract}
Ah, Betty, não veja em mim, nas minhas roupas senão uma alegoria: quero erguer para os outros uma imagem da coragem que não tive. Passeio-me tal como quero, ataviado e livre, mas ai de mim, é dentro de uma jaula que o faço. É esta a única liberdade que possuímos integral: a de sermos monstros para nós mesmos.
\end{abstract}

Há algo de profundamente perturbador nessa figura, o que se percebe na maneira como a (des)entenderam as demais personagens da obra, mas também nas leituras que ela tem recebido da própria crítica literária. Incompreensível para a época que a forjou, assim como seu contemporâneo Diadorim, personagem central do Grande Sertão: Veredas (1956), de Guimarães Rosa, terá chegado o momento em que as monstruosidades de tais figuras sejam compreendidas não a partir da Norma, mas sim de leituras igualmente monstruosas?

Amara Moira é travesti, feminista, professora, doutora em teoria e crítica literária pela Unicamp (com tese sobre o Ulysses, de James Joyce) e autora do livro autobiográfico E se eu fosse puta (hoo editora, 2016), do capítulo "Destino Amargo", publicado em Vidas trans - A coragem de existir (Astral Cultural, 2017), e do monólogo em pajubá "Neca", presente na antologia LGBTQIA+ A Resistência dos Vagalumes (Nós, 2019). 


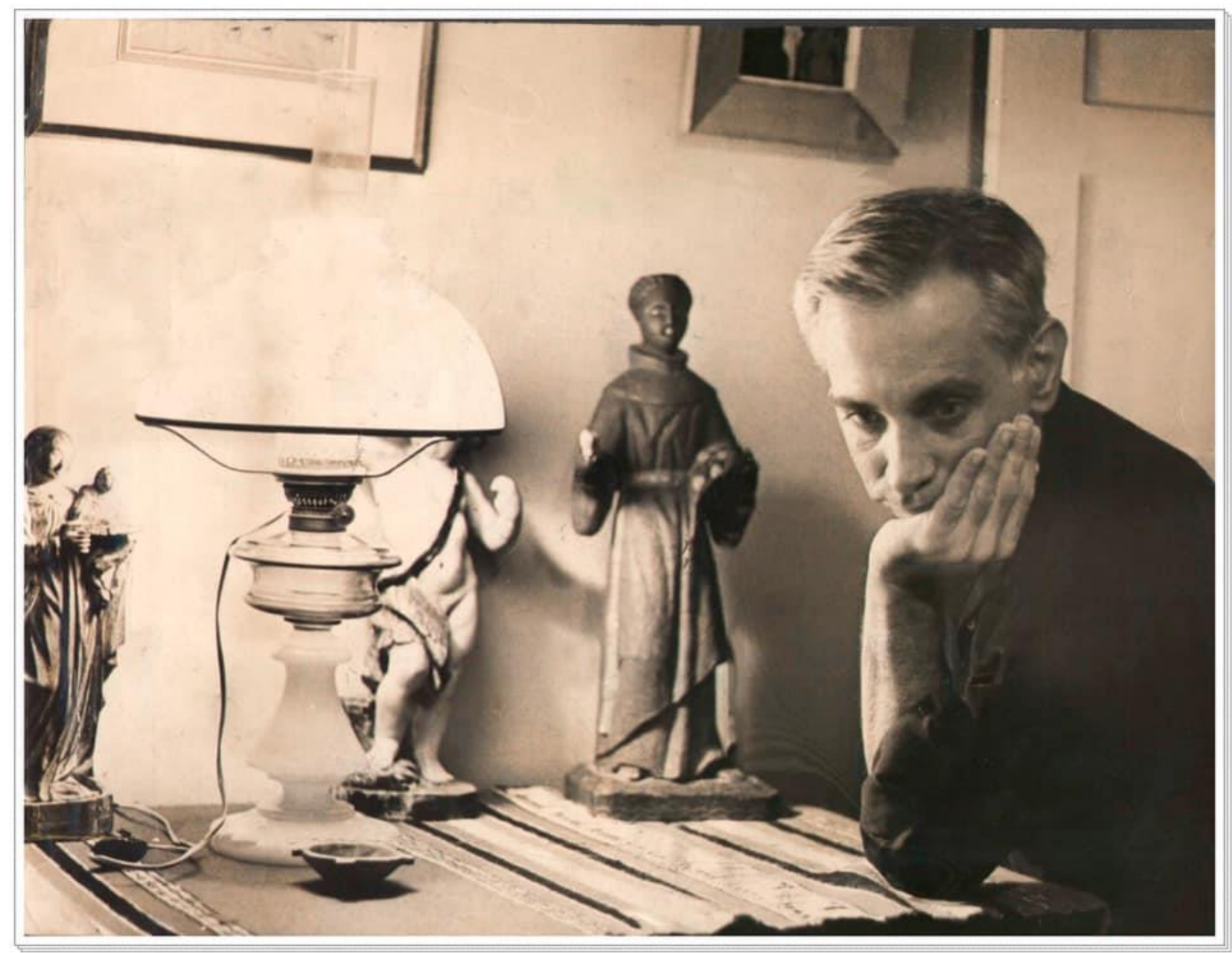

Lúcio Cardoso (década de 1960). Acervo da família 


\section{opiniães}

\section{jülio castañon Quimarães}

Minhas lembranças iniciais de leitura da Crônica da casa assassinada de Lúcio Cardoso não são muito específicas, talvez sejam um tanto misturadas. De fato, não me lembro de quando li o livro pela primeira vez - devo ter lido bem jovem. Provavelmente terá sido uma leitura meio superficial, ainda que eu possa ter ficado impressionado com a organização complexa do livro, associada aos segredos da narrativa. O que entra de mistura na minha lembrança são as imagens do filme de Paulo César Saraceni. Acho que vi o filme antes de ler o livro, de modo que uma ou outra imagem do filme se sobrepunha ao texto, ou melhor, este se tornava visível na lembrança dessas imagens do filme, ainda que naturalmente este fosse extremamente mais simples, limitado mesmo. Muito tempo depois é que vim a reler o livro - releitura que se repetiu muitas vezes, pois me vi envolvido na sua edição para a coleção Archivos, tendo eu ficado incumbido de preparar a edição crítica. Lidar com as várias versões manuscritas e datilografadas foi de fato redescobrir o romance em processo; acompanhar certas modificações - de frases, de caracterização de personagens, de gênero dos textos (já que o romance é composto por depoimentos, diários, cartas etc.). Era de certo modo uma forma privilegiada de leitura. É claro que nesse tipo de leitura se corre o risco de ficar preso a detalhes, minúcias, e perder a visão de conjunto. Mas me parece que o aspecto sombrio de todo o livro impede isso, leva o leitor a se envolver com a trama que existe na trama de sua configuração. Sei que isso é uma obviedade sobretudo para quem estuda a obra, mas a descoberta dessa dimensão é importante, até mesmo fundamental para quem lê o romance. Por fim, o resultado dessa minha leitura/trabalho acabou - ainda bem! - se sobrepondo àquela primeira leitura, despreparada, embalada pelas imagens do filme.

Júlio Castañon Guimarães é poeta, tradutor. doutor em Letras pela Universidade Federal do Rio de Janeiro e pesquisador aposentado pela Fundação Casa de Rui Barbosa. Autor de, entre outros, Poemas [1975-2005] (7Letras/Cosac Naify, 2006), Se dispersão (7Letras, 2017) e Em viagem (Tipografia do Zé, 2017). Recentemente, publicou a tradução integral de As flores do mal, de Baudelaire (Companhia das Letras, 2019). E-mail: juliocastanon@uol.com.br. 
- Houve tempo - disse ele [Timóteo] quase de costas para mim - em que achei que devia seguir o caminho de todo o mundo. Era criminoso, era insensato seguir uma lei própria. A lei era um domínio comum a que não podíamos nos subtrair. Apertava-me em gravatas, exercitava-me em conversas banais, imaginava-me igual aos outros. Até o dia em que senti que não me era possível continuar: por que seguir leis comuns se eu não era comum, por que fingir-me igual aos outros, se era totalmente diferente? Ah, Betty, não veja em mim, nas minhas roupas, senão uma alegoria: quero erguer para os outros uma imagem da coragem que não tive. Passeio-me tal como quero, ataviado e livre, mas ai de mim, é dentro de uma jaula que o faço. É esta a única liberdade que possuímos integral: a de sermos monstros para nós mesmos.

Diário de Betty (I) Crônica da casa assassinada. Lúcio Cardoso. 


\section{opiniães}

\section{xikito affonso ferreira}

Este extraordinário romance de Lúcio Cardoso, remonta à moral católica da primeira metade do séc. XX: o grande pecado humano é questão de costumes. $\mathrm{E}$ dá-se na ordem individual: é a libido a oportunidade de recusarmos a Deus. Nas palavras do teólogo canadense Pe. Paul-Éugene Charbonneau (1925-1987), a questão moral acompanhava a ideologia, também maniqueistamente, na primeira metade do séc. $\mathrm{XX}$, quando uma cortina de ferro dividia o mundo em duas metades estanques: o Ocidente democrático e no Leste um regime totalitário. $\mathrm{O}$ homem puro era o casto. Tal veia puritana não tinha cerimônia sequer com o casamento, onde o sexual justificava-se enquanto procriador apenas.

Pois tal ambiente foi atropelado pelo freudianismo, que eliminou a culpa individual e justificou o homem e as demandas da carne.

Meados do século passado, o Concilio Vaticano II introduziu na moral católica outra categoria: a culpa social - as injustiças geradas por sistemas pouco cristãos.

Lúcio Cardoso já não viveu a descontração acima trazida por Joao XXIII. Lúcio experimentou em cheio, na plena intimidação da consciência pesada, a dupla condição de fé profunda e conduta pessoal conflitante com o sexto mandamento. Sobre isso, vale à pena ler o grande crítico literário paulista Nogueira Moutinho (1933-1991). Bom mineiro, Lúcio herdou o fervor comum em sua gente. O romancista era muito ligado, além de a Carlos Drummond de Andrade, a Murilo Mendes e a outra expressão da espiritualidade nacional - Octavio de Faria - autor de A tragédia burguesa, em 15 volumes, best-sellers nos anos 1940. Octavio retrata a classe social que voltou as costas para Deus e a cultura do pecado da carne.

Pois Lúcio não era homem de meias medidas. Marcava seu espírito: o não diletantismo, o recusar-se a passear pelos temas humanos sem compromisso,

Escritor, memorialista e biógrafo. Publicou os livros: Estarei Delirando? (Miró 2013); Histórias de meu avô Tristão (Azulsol Editora, 2015, indicado ao Prêmio Jabuti daquele ano); Quem nunca olhou nos olhos mansos dos animais ferozes (Azulsol, 2017). E-mail: xikito@iaaf.com.br. 
como bem assinalou Alceu Amoroso Lima. Na Crônica, os personagens trazem cada um seu próprio desvio de conduta e paira no ar e nas fisionomias uma fortíssima carga erótica. Mas, no caso de Lúcio, ele exponenciava o sentimento de culpa sendo a um só tempo fervoroso e homossexual. Lúcio recebia e frequentava uma turma marginalizada por este traço e de vez em quando mergulhava nesse grupo. À Rachel de Queiroz, sua amiga escritora, que indagava por onde andara, Lúcio respondia: "No inferno".

O trágico Lúcio provou outras gotas do fel da vida, seus últimos seis anos de existência foram como vítima de um derrame, obrigando-o a pintar com a mão esquerda e a forçar passagem da fala pela boca torta. A escritora cearense bem o resumiu: "o menino que era um arcanjo rebelde". 




Lúcio Cardoso com a praia de Ipanema ao fundo Fotografia de Martim Gonçalves [década de 1930]. Acervo Instituto Martim Gonçalves 


\section{newton vieira}

\section{A CRÔNICA DE LÚCIO CARDOSO EM MINHA VIDA}

Li algures que a Crônica da casa assassinada, de Lúcio Cardoso, sacudiu o ambiente literário quando de seu lançamento em 1959. Pois bem. Sacudiria igualmente minha estrutura íntima quando tive a oportunidade de lê-la pela primeira vez, aos 16 anos, em exemplar emprestado pela professora de Português Antônia Cleusa Guimarães. Na verdade, a leitura desse romance de cunho introspectivo não apenas foi, mas continua sendo para mim deveras impactante. Sempre que possível, volto a mergulhar no clássico cardosiano e deparo com nuanças curiosas, aspectos insólitos, como se a obra me fora totalmente desconhecida.

Nascido e criado em Curvelo, terra natal de Lúcio, cidade conservadora e de arraigados princípios religiosos, eu era um adolescente em conflito consigo mesmo no momento que a Crônica me caiu nas mãos. Minha cabeça pesava de dúvidas em vários campos, inclusive no da sexualidade. De quebra, atraía-me também a ideia de ingressar em um seminário e me ordenar padre. Logo o contato com a história da sombria chácara dos Meneses, com direito ao incesto vivido por André e Nina, trazendo ao mesmo tempo intertextualidade bíblica, a exemplo da passagem da ressurreição de Lázaro, deixar-me-ia ainda mais atordoado, a partir mesmo do título. E mais reflexivo eu ficaria ante a situação de Timóteo, homossexual recluso, condenado à cruz da rejeição no próprio seio familiar.

Dificuldades se me apresentaram na compreensão da trama (daí a necessidade de releituras) em virtude da complexa técnica narrativa, marcada pela análise multifocal dos fatos e das personagens, em cartas, diários, depoimentos, confissões. Foi preciso cair muita areia da ampulheta para que este leitor percorresse os meandros do universo cardosiano sem se perder tanto.

Escritor, poeta e jornalista. Especialista em Gestão Estratégica de Comunicação. Diretor de redação da revista de cultura Pequi Magazine. Gerente de Comunicação da Prefeitura Municipal de Curvelo/MG, cidade onde reside. Pertence à Academia Municipalista de Letras de Minas Gerais - AMULMIG. Dentre outros trabalhos, publicou: Memória afetiva em Maria Helena Cardoso e outros ensaios, Pórtico poético (poesias) e Laçador de nuvens (poesias). Email: newtonvieiracvo@gmail.com. 


\section{opiniães}

Transcorridos sóis e luas, eis-me a considerar Crônica da casa assassinada verdadeiro divisor de águas na minha vida, porquanto tenha "assassinado" algumas de minhas convicções, além de me aguçar o espírito crítico e me tornar mais forte para o enfrentamento das vicissitudes. E mais: nas páginas do romance, muito do inconsciente coletivo de minha gente, a curvelana; muito de curvelanidade; dir-se-ia até de curvelanice.

Nos Diários, Lúcio aventou a hipótese de a Crônica já ter vindo a lume envelhecida. Certamente equivocou-se. Para mim, a obra permanece atual, doze lustros depois de lançada. E me fascina... E me reserva surpresas... Ainda. 


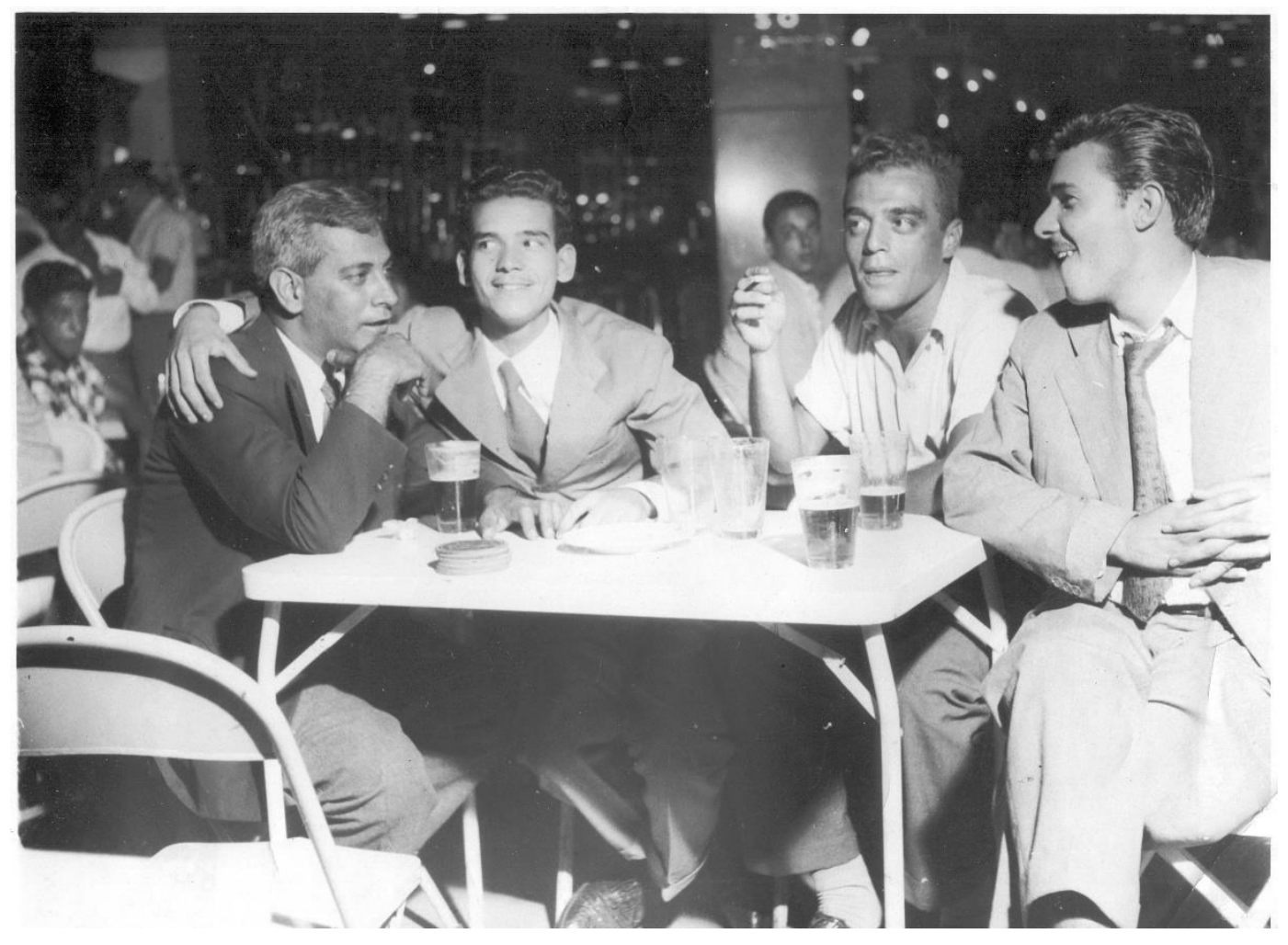

Lúcio Cardoso e amigos no bar Amarelinho, no Rio de Janeiro [década de 1950]. Acervo da família 


\section{opiniães}

\section{georóemoura}

\section{A CRÔNICA DA CASA ASSASSINADA: MAKING OF DE UM ROTEIRO}

O romance de Lúcio Cardoso, Crônica da casa assassinada, caiu em minhas mãos acompanhado de uma frase: "Quero fazer deste livro, um filme". O que poderia parecer um pedido banal, na prática, norteou a minha leitura. É muito diferente ler um livro por fruição ou ler um romance pensando na adaptação para um roteiro de cinema. Comecei devagar, mas logo fui arrebatado pelas paixões de Nina, Ana e de toda a família Meneses, nesta narrativa barroca, vertiginosa e febril, que mergulha sem medo na tragédia do desejo.

Cardoso fez uma obra-prima. E obra-prima, diferente da literatura de entretenimento, é armadilha perigosa a ser transposta até se chegar a um roteiro. Ainda mais quando se trata de um livro em forma de "diário" de vários personagens, que manifestam diferentes pontos de vistas dos mesmos fatos vividos. Para acrescentar uma nova camada de complexidade à narrativa, o livro se passa em dois tempos: no momento presente e dezesseis anos depois. Deslocamento de tempo é algo simples na literatura, já no cinema é preciso pensar em troca de elenco, pois com a variação das idades, às vezes, precisamos de diferentes atores ou de recorrer ao envelhecimento pela maquilagem.

Depois da primeira leitura de Crônica..., fiquei meses sem conseguir voltar ao livro, que me olhava da estante, repleto de rabiscos e comentários. Como método de trabalho, costumo anotar à caneta nas margens do volume, num diálogo imaginário com o autor e os seus personagens. Quando eu pegava o livro para reler trechos, ele ardia em minhas mãos. Devolvia. Ia cuidar de outras escritas. Até que, um dia, fui novamente tragado e não consegui mais me desconectar desta trama poderosa, repleta de personagens fascinantes.

George Moura é roteirista das séries Amores roubados (2014), Onde nascem os fortes (2018) e de filmes como Redemoinho (2016), Getúlio (2014) e Linha de passe (2008). Neste momento, escreve uma nova adaptação para o cinema da Crônica da casa assassinada, que será dirigida por José Luiz Villamarim. Em 2021, estreará uma nova série escrita por ele, em parceria com Sergio Goldenberg, Onde está meu coração, no Globo Play. 
São inúmeras as escolhas a serem feitas no processo de adaptação de um original. Como exemplo, trato de uma dessas escolhas. A de como começar um filme à luz do começo de um livro.

No livro de Lúcio Cardoso, Nina, já na primeira página, está morta e rodeada de velas. Corpo na mesa da sala, sendo velado por André, o suposto filho. O autor escreve assim:

... Meu Deus, que é a morte? Até quando, longe de mim, já sob a terra que agasalhara seus restos mortais, terei de refazer neste mundo o caminho do seu ensinamento, da sua admirável lição de amor, encontrando nesta o aveludado de um beijo - "era assim que ela beijava" - naquela um modo de sorrir, nesta outra um tambor de uma mecha rebelde dos cabelos - todas, todas essas inumeráveis mulheres que cada um encontro ao longo da vida, e que me auxiliarão a recompor, na dor e na saudade, essa imagem única que havia partido para sempre? Que é, meu Deus, o para sempre...

Ao reler as primeiras linhas, logo me fiz uma primeira pergunta. Deveria começar um filme com a protagonista morta? $\mathrm{Na}$ literatura de Cardoso, essa escolha funciona perfeitamente, mas no roteiro gostaria que o espectador tivesse a possibilidade de não saber, a priori, o destino final de Nina na trama. E será que, nesta nova adaptação, ela vai ficar viva? Sem spoiler. No filme dirigido e escrito por Paulo César Saraceni, em 1971, Nina, vivida pela inesquecível Norma Bengell, também jaz nas primeiras imagens. Fiz então uma outra escolha e começo assim o roteiro do filme Casa Assassinada:

\section{INT. FUNDO PRETO}

"A mocidade tem o cheiro das violetas". Lúcio Cardoso

INT. MANSÃO DOS MENESES/ VARANDA + JARDIM - DIA Anos 50. A casa é imponente, mas já revela os sinais do declínio financeiro da família Meneses, no desgaste da fachada da casa e das janelas. Um jardim sem cuidados e um canteiro das violetas está seco, vazio e sem flor. ANDRÉ - 18 anos -, filho de Nina e Valdo. Ele limpa a espingarda de caça. VALDO - 54 anos -, envelhecido, se aproxima, ainda sem ser visto por André. 


\section{opiniães}

VALDO

Gosto de ver você ocupado com as coisas desse mundo.

ANDRÉ

(sem olhar Valdo)

De vez em quando, precisa lubrificar.

Valdo observa André.

VALDO

Você pode me dar um minuto?

ANDRÉ

Pois não, meu pai.

VALDO

É um assunto um pouco triste, filho. (T) Vejo que você tem uma caçada.../

ANDRÉ

Não, não tenho. Estava apenas limpando.

VALDO

Que pena. Uma caçada agora me agradaria.

ANDRÉ

Por quê?

VALDO

Porque... É preciso, André. Não me pergunte as razões, que eu não posso dar agora, mas tenho necessidade de que você se afaste da casa um ou dois dias.

André intui e deduz do que Valdo está tratando.

ANDRÉ

É ela?

Valdo não responde.

ANDRÉ 
Tenho certeza que é dela que o senhor está falando.

Valdo assente com um gesto positivo.

\author{
ANDRÉ \\ (calmo) \\ Então, meu pai, não vou à caçada.
}

\title{
VALDO
}

Se pensa que eu quero impedir que você veja sua...

(não consegue concluir a frase, hesita)

Está enganado. Estou pedindo apenas um prazo.

\section{ANDRÉ}

Ela vai chegar?

VALDO

Vai.

(em dúvida)

Acredito que, dessa vez, vai ficar para sempre.

\section{ANDRÉ}

(numa revolta contida)

Por que nunca ninguém me fala, por que ninguém diz nada sobre ela? O que ela fez, por que me escondem tudo?

Valdo não responde. André, espingarda na mão, encara Valdo. É como se André pudesse, num repente, atirar em Valdo.

\section{VALDO}

(com dificuldade)

Foram muitos erros no passado, mas tudo está perdoado. Só tenho um pouco de medo do seu reencontro com ela, são muitas...

(emotivo)

Mas o que importa é que sua mãe... Nina vai voltar.

ANDRÉ

(emocionado)

O senhor jura que nunca mais ela vai abandonar a gente? 


\section{opiniães}

VALDO

Juro.

André, em silêncio, olha para Valdo.

EXT. MANSÃO DOS MENESES/ JARDIM - ENTARDECER

Legenda: 18 anos antes.

O jardineiro ALBERTO - 18 anos -, com traços e gestos muito parecidos com os de André, cuida do lindo e impecável jardim de violetas.

Tela inteira. Terra escura cultivada por mãos hábeis. De repente, o mau uso de uma faca dá um corte na mão que sangra e pinga na terra.

EXT. MANSÃO DOS MENESES/ JARDIM + VARANDA ENTARDECER

Os sinais do declínio financeiro são bem menores, mas tudo já se decompõe lentamente.

\section{INT. MANSÃO DOS MENESES/ SALA - ENTARDECER}

Vestido com a melhor roupa, VALDO - 36 anos -, à espera, disfarça a ansiedade. A eficiente empregada BETTY - 55 anos se aproxima, entrega um telegrama e vai para um canto da sala. Valdo abre o envelope e ao ler o telegrama fica muito desapontado.

ANA - 30 anos - chega, seguida por DEMÉTRIO - 42 anos -, irmão de Valdo. Ambos também bem trajados.

\section{DEMÉTRIO}

Você está indo buscar Nina?

Valdo tenta disfarçar a decepção.

VALDO

Ela não vem -

ANA

Não vem!?

VALDO

Ela não vem... (T) Hoje - 


\section{DEMÉTRIO}

Algum problema?

VALDO

(mostra o telegrama)

Nenhum. Só deve chegar amanhã ou depois.

Valdo se abate, não suporta ficar mais um segundo sob o olhar de Demétrio e Ana. E sai.

Betty, discreta, observa afastada à espera de uma nova ordem.

\section{BETTY}

(tenta contornar o mal-estar)

Melhor assim, temos mais tempo para pôr tudo em ordem e receber dona Nina como ela merece. (T) Licença.

Betty sai. Ana e Demétrio, desconfiados, se entreolham sem entender.

\section{EXT. MANSÃO DOS MENESES/ JARDIM - ENTARDECER}

Alberto, corpo jovem delineado, sem camisa, suado, mão envolta por um pano como curativo, segue no trabalho e água as plantas.

INT. MANSÃO DOS MENESES/ QUARTO DE NINA E VALDO - NOITE

Valdo, sozinho, vestido e insone, olha a cama de casal vazia. Ele caminha até a janela e contempla a escuridão. Ouve-se batidas na porta.

\section{VALDO}

Quem é?

\section{DEMÉTRIO}

(em off)

Sou eu.

Valdo fica em silêncio.

DEMÉTRIO (CONT.) 


\section{opiniães}

(em off)

Posso entrar?

Valdo não responde.

INT. MANSÃO DOS MENESES/ PORTA + CORREDOR QUARTO - NOITE

Demétrio diante da porta à espera da resposta. A porta se abre, não por inteiro, devagar. Valdo na penumbra.

\section{DEMÉTRIO}

Está tudo bem?

Valdo assente.

\section{DEMÉTRIO (CONT.)}

Você não acha que tudo isso é muito precipitado? Papai e mamãe não iriam gostar -

\section{VALDO}

Eles estão mortos, Demétrio. (T) Era isso?

Demétrio saindo.

\section{DEMÉTRIO}

Espero que você saiba o que está fazendo.

Valdo fecha a porta. E volta para a janela. Valdo olha...

EXT. RIO DE JANEIRO/ COPACABANA - ENTARDECER

Alguns meses antes. FB. Valdo, de luto, caminha à beira mar.

EXT. PENSÃO/ ESCADARIA + APARTAMENTO DE NINA NOITE

Alguns meses antes. FB. Valdo sobe as escadas quando ouve a discussão. Ele estaca e recua para observar pela porta entreaberta do apartamento.

Na sala, NINA - 25 anos -, deslumbrante, diante do pai, ROSENDO - 71 anos -, asmático, numa cadeira de rodas.

ROSENDO 
Nina, eu lhe perdi... Perdi inteira. Você vai ter que casar! É a minha palavra! Eu exijo a sua resposta!

NINA

(descontrola-se)

Nunca, prefiro morrer! Mil vezes a morte!

\section{ROSENDO}

(grita)

Você sempre fez o que quis, nunca teve pena de seu pai. Será que pelo menos agora -

NINA

(aos berros)

Não! E não! Não vou casar com ninguém!

\section{ROSENDO}

Filha! Volte aqui! Minha filha!

Nina bate a porta e sai em dispara. Valdo, absolutamente encantado por Nina, se esconde para não ser visto. Ela passa veloz. Em seguida, Valdo segue pelas escadas atrás de Nina.

\section{EXT. RIO DE JANEIRO/ RUA - ENTARDECER}

Alguns meses antes. FB. Nina, apressada, não percebe que é seguida por Valdo. Nina para e, aflita, começa a chorar. Valdo se aproxima com delicadeza.

VALDO

Desculpa, mas eu vi... Tudo.

Nina se assusta, enxuga as lágrimas e fica arredia.

NINA

O que o senhor quer!?

VALDO

(hesita)

Um sorriso... Nada mais.

EXT. RIO DE JANEIRO/ COPACABANA - ENTARDECER 


\section{opiniães}

Alguns meses antes. FB. Valdo e Nina, num banco, à beira mar, conversam.

NINA

(sorri sedutora)

Meu pai era viciado em cartas e perdeu uma aposta.

VALDO

E o que estava em jogo?

NINA

Pode parecer estranho, mas era eu. Meu pai me apostou numa partida com um amigo.

VALDO

Desculpe perguntar, você é casada, solteira, noiva?

NINA

Não é simples responder. Meu pai morreu há pouco tempo e eu fiquei sozinha no mundo.

\section{VALDO}

Também perdi meus pais. Muitas noites sonho que eles ainda estão vivos.

NINA

Lamento. (T) O Coronel, com quem meu pai jogava cartas, passou a ser a minha única possibilidade.

VALDO

E você... -

NINA

Ele passou a me ajudar. Ao meu pai, ele disse: "você não está jogando a sua filha. Você está jogando com a felicidade dela!”.

Nina, triste, se emociona.

NINA (CONT.)

(emotiva)

Minha felicidade... 


\section{VALDO}

Você não pode viver assim para sempre, por conta de um jogo de cartas.

NINA

Qual é mesmo o seu nome?

VALDO

Valdo Meneses.

NINA

O senhor parece ser um homem bom.

Valdo pega a mão de Nina que sorri.

VALDO

(encantado)

Só você podia me trazer de volta a vida.

INT. MANSÃO DOS MENESES/ QUARTO DE NINA E VALDO - NOITE

$\mathrm{Na}$ cadeira, Valdo, insone, olha para a parede, que tem uma mancha de infiltração.

EXT. ESTAÇÃO DE TREM/ PLATAFORMA - ENTARDECER Dia seguinte. Sete malas já desembarcadas. O trem já partiu. Nina, roupa bem mais modesta, ao lado das malas. Ela olha em todas as direções e não é esperada por ninguém. Os poucos que desembarcaram já se foram. Nina, sozinha, na estação.

Fim da sequência inicial. $O$ trecho acima é apenas um esboço do começo de um filme, que um dia existirá. Há, na escolha, uma consequência imediata. Iniciamos a história com Nina e apresentamos o tempo futuro para depois voltar ao presente. E nesse tempo futuro, Nina ainda está vida.

O desafio de atravessar a "gigantesca espiral colorida" das 536 páginas de Lúcio Cardoso para chegar num roteiro de cerca de 100 páginas tem me acompanhado nos últimos meses. No coração uma batida forte e no horizonte uma seta, feita de palavras, que apontam para o infinito parafraseando Lúcio Cardoso: 


\section{opiniães}

Não são pessoas diferentes as que amamos ao longo da vida, mas a mesma imagem em seres diferentes. Hoje, calado, ainda sofro, mas sem aquela escuridão que tantas vezes me atirou contra mim mesmo. A vida me ensinou que a gente condena tudo o que ama, primeiro à agonia de nossa admiração, depois à insânia de nossos desejos. O medo de perder e de ser traído acompanha a gente a vida inteira. 
Que é o para sempre senão o existir contínuo e líquido de tudo aquilo que é liberto da contingência, que se transforma, evolui e deságua sem cessar em praias de sensações também mutáveis? Inútil esconder: o para sempre ali se achava diante dos meus olhos. Um minuto ainda, apenas um minuto - e também este escorregaria longe do meu esforço para captá-lo, enquanto eu mesmo, também para sempre, escorreria e passaria - e comigo, como uma carga de detritos sem sentidos e sem chama, também escoaria para sempre meu amor, meu tormento e até mesmo minha própria fidelidade. Sim, que é o para sempre senão a última imagem deste mundo - não exclusivamente deste, mas de qualquer mundo que se enovele numa arquitetura de sonho e de permanência - a figuração de nossos jogos e prazeres, de nossos achaques e medos, de nossos amores e de nossas traições - a força enfim que modela não esse que somos diariamente, mas o possível, o constantemente inatingido, que perseguimos como se acompanha o rastro de um amor que não se consegue, e que afinal é apenas a lembrança de um bem perdido - quando? - num lugar que ignoramos, mas cuja perda nos punge, e nos arrebata, totais, a esse nada ou a esse tudo inflamado, injusto ou justo, onde para sempre nos confundimos ao geral, ao absoluto, ao perfeito de que tanto carecemos.

Diário de André (conclusão) Crônica da casa assassinada. Lúcio Cardoso 


\section{opiniães}

\section{luiz carlos lacerda}

\section{A CASA ASSASSINADA: UMA CRÔNICA CONTEMPORÂNEA}

A primeira vez que ouvi falar de Lúcio Cardoso foi através de meu pai, João Tinoco de Freitas, que tinha produzido o longa-metragem Almas adversas (1948), um argumento de seu amigo Lúcio Cardoso, e convencido o próprio Lúcio à aventura de dirigir no ano seguinte $A$ mulher de longe, cujas filmagens seriam interrompidas e jamais retomadas.

Dele recebi as novelas $O$ enfeitiçado, Mãos vazias e $A$ professora Hilda e o romance Dias perdidos, que me tornaram um aficionado leitor do principal escritor do romance psicológico e me fizeram descobrir que nem só de Jorge Amado, Zé Lins e Graciliano Ramos se constituía a literatura brasileira.

Foi através do poeta Cláudio Murilo Leal, meu professor que me orientava na leitura dos poetas modernistas brasileiros e dos simbolistas franceses do século XIX, ao mesmo tempo em que me incentivava a escrever meus primeiros poemas - publicados por sua iniciativa na antologia Novos Poetas (Ed. Jovem, 1960), que conheci pessoalmente o meu escritor preferido e que marcaria a minha produção como cineasta.

Certa noite, em que o acompanhava ao Bar Jangadeiros, em Ipanema, ponto de encontro dos intelectuais e artistas, ele me apontou aquele homem moreno, levemente grisalho, identificando-o, para meu espanto e curiosidade. E assim fomos apresentados. O jovem poeta, adolescente, mas já admirador daquela obra densa, que misturava uma escrita sofisticada com o mergulho profundo na alma humana.

Desde então estabeleci uma comunicação direta com Lúcio - frequentando sua casa e levando a reboque minha melhor amiga, também poeta, Leila Diniz. E foi com ela, numa noite no apartamento onde ele morava, na Rua Joana Angélica,

Luiz Carlos Lacerda é cineasta, roteirista, produtor e poeta. Além de ter realizado filmes dedicados à obra de Lúcio Cardoso, como $O$ enfeitiçado (1968), Mãos vazias (1971), A mulher de longe (2012) e os recentes Introdução à música do sangue (2017) e O que seria deste mundo sem paixão? (2018), dirigiu o drama biográfico Leila Diniz (1987). 
próximo à Lagoa, que ouvimos do autor da Crônica da casa assassinada alguns trechos do manuscrito do livro que seria publicado naquele mesmo ano, Crônica da casa assassinada.

Arrebatados pela beleza literária e pela emocionada voz que escorria, melíflua, descrevendo os corredores que levavam ao quarto de Nina colhendo as violetas na janela, ao operístico personagem travesti Timóteo, trancado com seu discurso contra a moral burguesa da família mineira contra a qual Lúcio "lançava seu punhal”, à última noite de amor de André numa improvável relação incestuosa jamais revelada, às cartas e diários de personagens que teciam, aos poucos, e cada qual sob seu ponto de vista, a narrativa agônica e alucinada daquela metafórica mansão e retrato de uma sociedade mergulhada no preconceito, no conservadorismo e na decadência.

Em 1962, o autor foi vítima de um derrame que o impediu de continuar sua obra. Testemunhei, já em casa de Maria Helena Cardoso, sua irmã que o acolhera para o resto de sua vida, a batalha daquele artista que, com o limite dos dedos da mão esquerda, buscava agora através de traços e tintas, continuar se expressando, na incessante busca de narrar o que habitava ainda em seu "coração selvagem". "O pintor estava dentro dele esperando a sua hora, que poderia não vir, mas veio", escreveu Drummond apresentando a primeira exposição de suas pinturas em galeria. Foi numa dessas visitas que eu fazia frequentemente que, já trabalhando como Assistente de Direção de Nelson Pereira dos Santos, tive o desejo de fazer meu primeiro filme - relatando esse milagre movido pela necessidade que só os grandes artistas têm. Lúcio foi responsável pela minha estreia como diretor. $\mathrm{O}$ curta $O$ enfeitiçado (1968), que ele chegou a ver na pequena sala de projeção do laboratório em Botafogo, e cujo entusiasmo o fez me presentear com o argumento incompleto de Introdução à música do sangue, estreou no Festival de Brasília daquele ano, no dia de sua morte - cuja notícia recebi no palco, seguido de um silêncio da plateia lotada.

Já li e reli $A$ casa assassinada, título que nós, seus aficionados, abreviamos carinhosamente, em diversas edições. Assim como induzo sua leitura aos meus assistentes e alunos. Não me sentia amadurecido como cineasta para adaptá-lo para o cinema, e escolhi para meu primeiro longa-metragem seu romance Mãos vazias (1970), com Leila Diniz protagonizando-o, num certo sentido reverenciando aquela noite inesquecível que Lucio nos deu o privilégio daquela leitura. 


\section{opiniães}

Dediquei uma boa parcela de minha produção como cineasta à obra dele.

No ano de seu centenário (2012), depois de localizar parte dos negativos perdidos de sua inacabada incursão na direção cinematográfica em $A$ mulher de longe (1949), realizei um documentário homônimo com o texto pesquisado nos Diários, organizado por Ésio Macedo Ribeiro, um obstinado admirador da obra do escritor, e que foi lançado durante as homenagens ao centenário na Mostra de Cinema de Ouro Preto, seguido de exibições por todo o país, em cinematecas, museus, centros culturais, departamentos de letras das universidades, Biblioteca Nacional, Academia Brasileira de Letras e outros festivais de cinema.

Durante as pesquisas desse filme, no Arquivo de Lúcio Cardoso na Fundação Casa de Rui Barbosa, encontrei os manuscritos de Introdução à música do sangue, que ele me presenteara em 1968 e que eu havia perdido. Quase 50 anos depois, reuni recursos através de leis de incentivo e apoios do Polo Audiovisual de Cataguases e realizei o filme - lançado nas salas de cinema em 2017, depois de passar pelos festivais do Rio, Gramado e Montevideo, com boas críticas que destacavam o acerto na transposição da atmosfera e dos silêncios da literatura para as imagens.

Novamente debruçado sobre seus livros e seus personagens, escrevi e filmei o roteiro original de $O$ que seria deste mundo sem paixão?, frase de Timóteo, personagem da Crônica que recriei, mesmo depois da antológica interpretação de Carlos Kroebber na versão levada às telas (1971) por Paulo Cesar Saraceni. Neste, interpretado magistralmente por Fernando Melvim, sobre o texto de Dib Carneiro Neto, especialmente adaptado para a excelente montagem teatral de Gabriel Villela. O filme narra um hipotético encontro, depois da morte, entre Lúcio e o poeta Murilo Mendes, com os personagens de seus livros em busca de outros finais para suas histórias.

Entre eles, os de Mãos vazias, O desconhecido, Inácio, e - sempre - da Crônica da casa assassinada. Além do desabafo ideológico de Timóteo, o amor de André e Nina em seu leito de morte.

Este livro, com edições comentadas e publicado em vários países - o mais recentemente nos Estados Unidos -, marca a presença discreta mas permanente de nosso maior escritor. Vem sendo descoberto pelas novas gerações, como o foi por aquele adolescente que fui. 

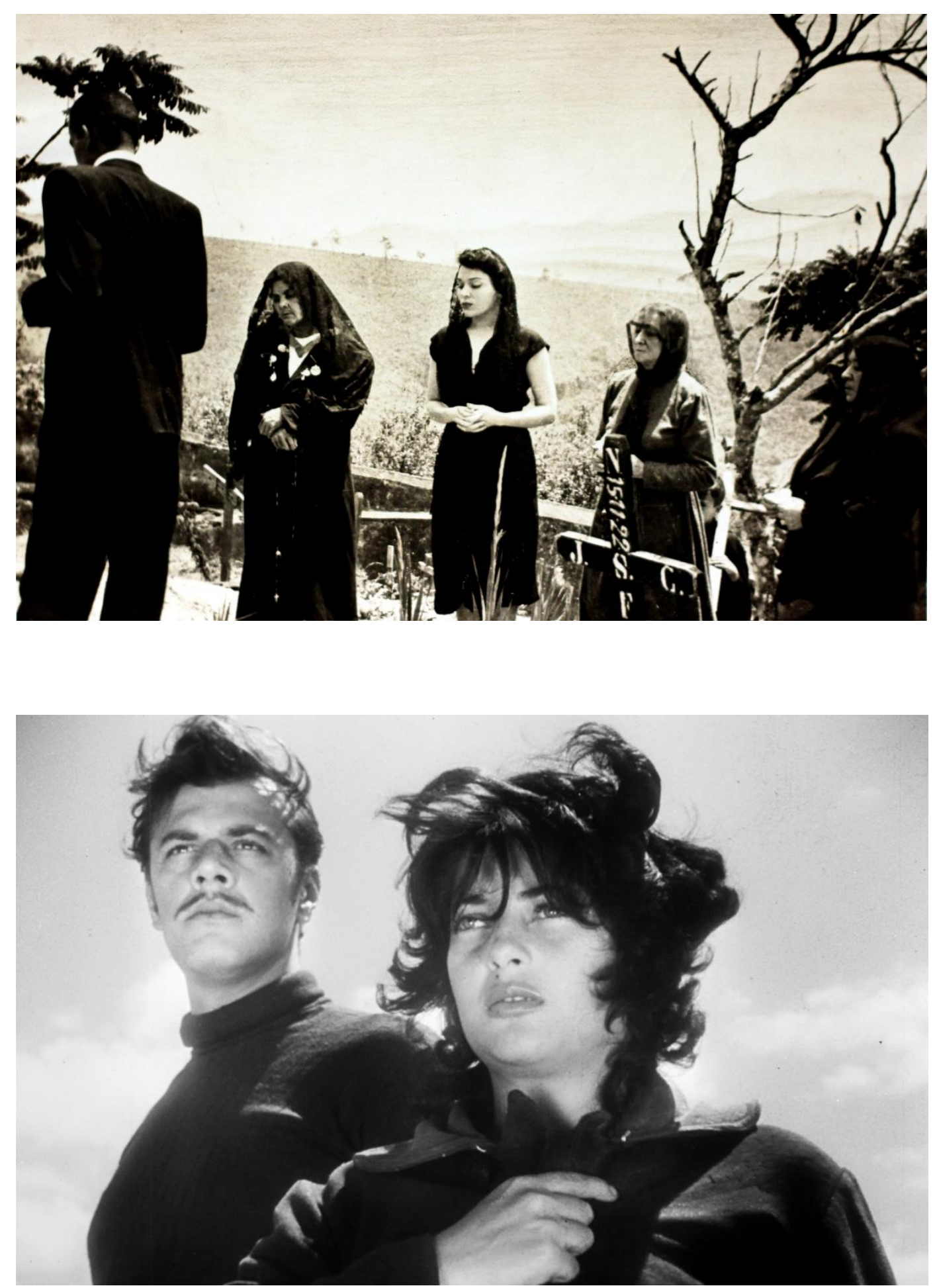

Dois stills do filme A mulher de longe [1949]. Acervo Luiz Carlos Lacerda 


\section{opiniães}

\section{ney costa santos}

Tantas vezes olhei da janela da casa de meus pais o prédio da esquina da Alberto de Campos com Joana Angélica, em Ipanema, onde morava Lelena e onde Lúcio Cardoso viveu.

Nas ruas as amendoeiras são as mesmas. Frondosas, com as folhas secas que entopem os bueiros, o mesmo odor enjoativo de suas flores.

Certamente Lúcio passou por ali vindo do Bar Veloso, ou indo para o Bar Lagoa.

O cheiro do mar, a sombra das árvores, a luz da Lagoa, a bela casa da esquina persistem como testemunhas do tempo em que caminhou por aquelas calçadas pensando em seus personagens.

A Rua Nascimento Silva, 107, onde morava Tom Jobim, fica perto dali.

Talvez os dois, Lúcio e Tom, algum dia beberam juntos nas mesas dos bares que frequentavam, mas o verdadeiro encontro se deu entre as linhas da Crônica da Casa Assassinada e as notas da trilha composta por Tom para o filme de Paulo César Saraceni.

Lúcio, Tom e meus pais já não estão mais por aqui, mas juro que todas as vezes que volto à janela e olho para o edifício pintado de rosa esmaecido ouço, da Lagoa e entre as amendoeiras, a trilha da Casa Assassinada.

Cineasta e professor da Pontifícia Universidade Católica do Rio de Janeiro (PUC-Rio). 


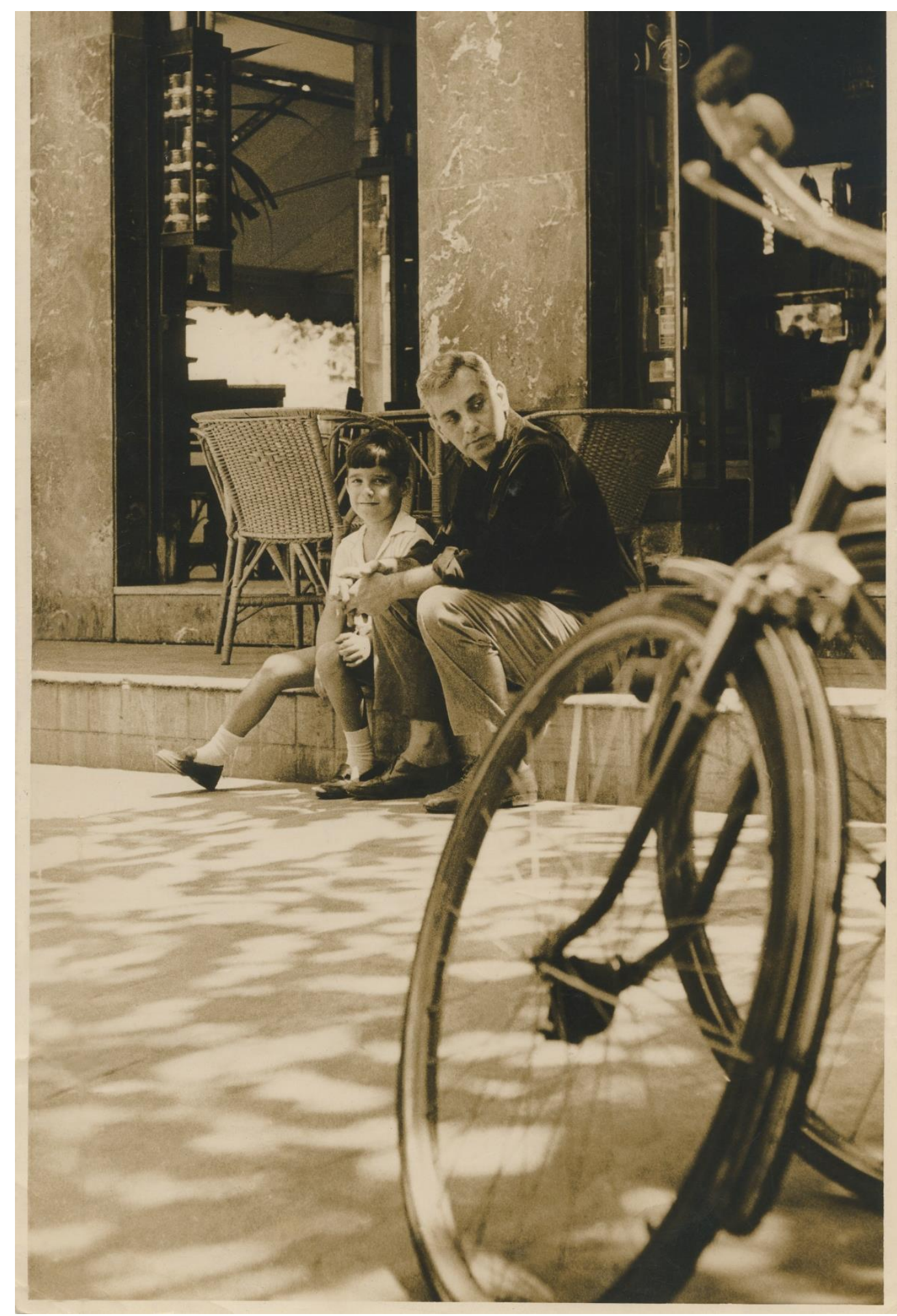

Lúcio Cardoso no Bar Veloso [1959].

Acervo da família 


\section{opiniães}

\section{dib carneiro neto}

Um livro seminal. Um autor luminoso. Um estilo incomparável. Levar a literatura epistolar de Lúcio Cardoso, em sua Crônica da casa assassinada, para os palcos, a pedido de outro genial mineiro, o diretor Gabriel Villela, foi um dos maiores desafios de minha trajetória de dramaturgo. Eu já era, desde a adolescência, um apaixonado fervoroso desse romance montado como um quebra-cabeças, uma colagem de fragmentos de cartas e bilhetes dos membros de uma mesma família e seus agregados e visitantes. Não podia fazer uma adaptação que não reverenciasse a obra, como expoente máximo de nossa melhor literatura nacional. Eu me senti na obrigação de manter no palco o fluxo das missivas. Me recusei a tomar o caminho de outros adaptadores, que retiravam do livro apenas sua trama e ignoravam a forma epistolar. Eu quis as cartas em cena. Lúcio merecia isso. E Villela comprou minha reverência com respeito. Não que o tempo todo os atores tivessem cartas à mão e ficassem lendo, mas algumas poucas cenas remetiam ao velho hábito de se comunicar por escrito. Posso ainda destacar do meu recorte de adaptador a opção por dividir os personagens e as cenas em "os de fora" e "os de dentro" da casa. Já que a casa da família Meneses é a própria obra, é a essência da trama, é o microcosmo onde tudo se desenvolve, nada melhor do que referenciar tudo a partir dela: "os de fora" eram os que a frequentavam com desconfiança e medo do mistério nela contido (um padre, um farmacêutico, um médico, o jardineiro) e "os de dentro" eram os densos e tensos integrantes daquele clã encruado em si, moldado nas rachaduras de paredes envelhecidas por tantos segredos. Por fim, minha adaptação teatral ganhou o brilho dos panos de figurinista exímio de Villela, um sempre inspirado encenador, que traduziu como ninguém no palco a expressão que tanto cabe ao modo mineiro de viver: "por debaixo dos panos".

Jornalista, escritor e dramaturgo. Sua adaptação teatral de Crônica da casa assassinada fez temporada em 2011 no Teatro Maison de France, no Rio de Janeiro e no Sesc Vila Mariana, em São Paulo. 
Até o instante em que, diante do meu espelho, percebi seu olhar sobre mim e li nele todo o desprezo que ia na sua alma. Não me senti propriamente humilhada, nem infeliz, pois era indiferente ao que ele pensasse a meu respeito. Mas aquele olhar, nascido de tão cálidas profundezas, como que demudou aos meus olhos a presença tangente da realidade: acordei também, e pela primeira vez circunvaguei a vista em torno, atônita, sem compreender direito o que se passava. Surpreendeu-me em primeiro lugar o silêncio que havia em torno da minha pessoa; sim. jamais presenciara quietude igual, uma tão completa ausência de ritmos ou de dissonâncias; era qualquer coisa álgida, fluida, escorregadia como o sono da morte - e era isto o que denunciava a minha mediocridade. No inferno deve haver um lugar à parte para os medíocres, e o próprio Satā, contemplando a presa inerte. tridente erguido, deverá indagar de si mesmo um tanto perplexo: “Que farei com isto, se até o sofrimento em sua presença diminui de intensidade"?

Primeira confissão de Ana Crônica da casa assassinada. Lúcio Cardoso. 


\section{opiniães}

\section{denilson lopes}

\section{CÂNCER SOBRE VIOLETAS}

Não me lembro a primeira vez em que li a Crônica da casa assassinada, de Lúcio Cardoso, mas, assim que fiz a leitura, decidi inclui-lo em minha tese de doutorado e primeiro livro Nós os Mortos: Melancolia e Neobarroco (Rio de Janeiro, 7letras, 1999) na linhagem dos romances e filmes de decadência de famílias patriarcais, junto com A menina morta, de Cornelio Penna, Ópera dos mortos, de Autran dourado, Leopardo, adaptação feita por Luchino Visconti da obra de Giuseppe Tomasi di Lampedusa, Salão de música, de Satyajit Ray, e Soberba, de Orson Welles. Era bem claro que eu não queria fazer uma pesquisa monográfica - nem sobre um autor, nem sobre um livro -, era mais um esforço comparativo de mapear uma sensibilidade melancólica, no sentido benjaminiano, e um imaginário neobarroco, problematizando as formulações hispano-americanas.

A busca desta linhagem também está na minha própria leitura da Crônica, pensada a partir de uma linhagem da diferença. $\mathrm{Na}$ época, eu estava começando a ter contato com os Estudos Queer, de forma que ela também poderia ser chamada de uma linhagem queer, feita da ruptura das hetero-homo-trans-normatividades, uma linhagem de dissidência sexual, poderia se dizer hoje.

De 1999 em diante me afastei da Crônica e desse mundo que só mais recentemente tem me retornado, novamente não como um livro isolado, mas um feixe de relações numa constelação que aponta para um outro Modernismo, para o qual a sobrevivência de uma sensibilidade marcada pela decadência do ouro em Minas Gerais e do café do Vale do Paraíba joga uma sombra ou mais do que isso sobre o Modernismo de 1922. Nessa constelação, longe de utopias e de velocidades, me interessa a morte, a destruição, o caos como centro da experiência moderna feita longe dos centros urbanos: um modernismo rural.

$\mathrm{Na}$ juventude, ter sido gótico, lembro agora, talvez tenha contribuído para eu ter me aproximado da Crônica. Passada a metade da vida, Crônica me vem como uma genealogia do fracasso, tão distante do derrotismo, como a melancolia de uma idealização do passado.

Professor Associado da Escola de Comunicação da Universidade Federal do Rio de Janeiro (UFRJ). E-mail: noslined@bighost.com.br. ORCiD: https://orcid.org/0000-0002-6306-5245. 
Os seres estranhos que aí habitam não pertencem mais ao passado, nem terão lugar no futuro. Para eles, o fim do mundo já aconteceu e talvez tenhamos muito o que aprender com eles. Nenhuma paz - a não a ser das paisagens devastadas, das cidades mortas, da reconquista da natureza, das ruínas. Nenhuma salvação apenas um mundo em que o ser humano se eclipsa.

Cartas, depoimentos e memórias - sempre ficções, nunca testemunhos -, criam uma diversidade de vozes, mas que também emergem e giram em torno de uma família, de um pântano em que eles se afundam. É por dentro que a morte e a destruição ocupam gradualmente o seu lugar, numa implosão a partir de um catolicismo transgressor, sem perder o apelo da beleza, sintetizado na imagem que Lúcio Cardoso faz da Crônica da casa assassinada: "um câncer sobre um canteiro de violetas". 


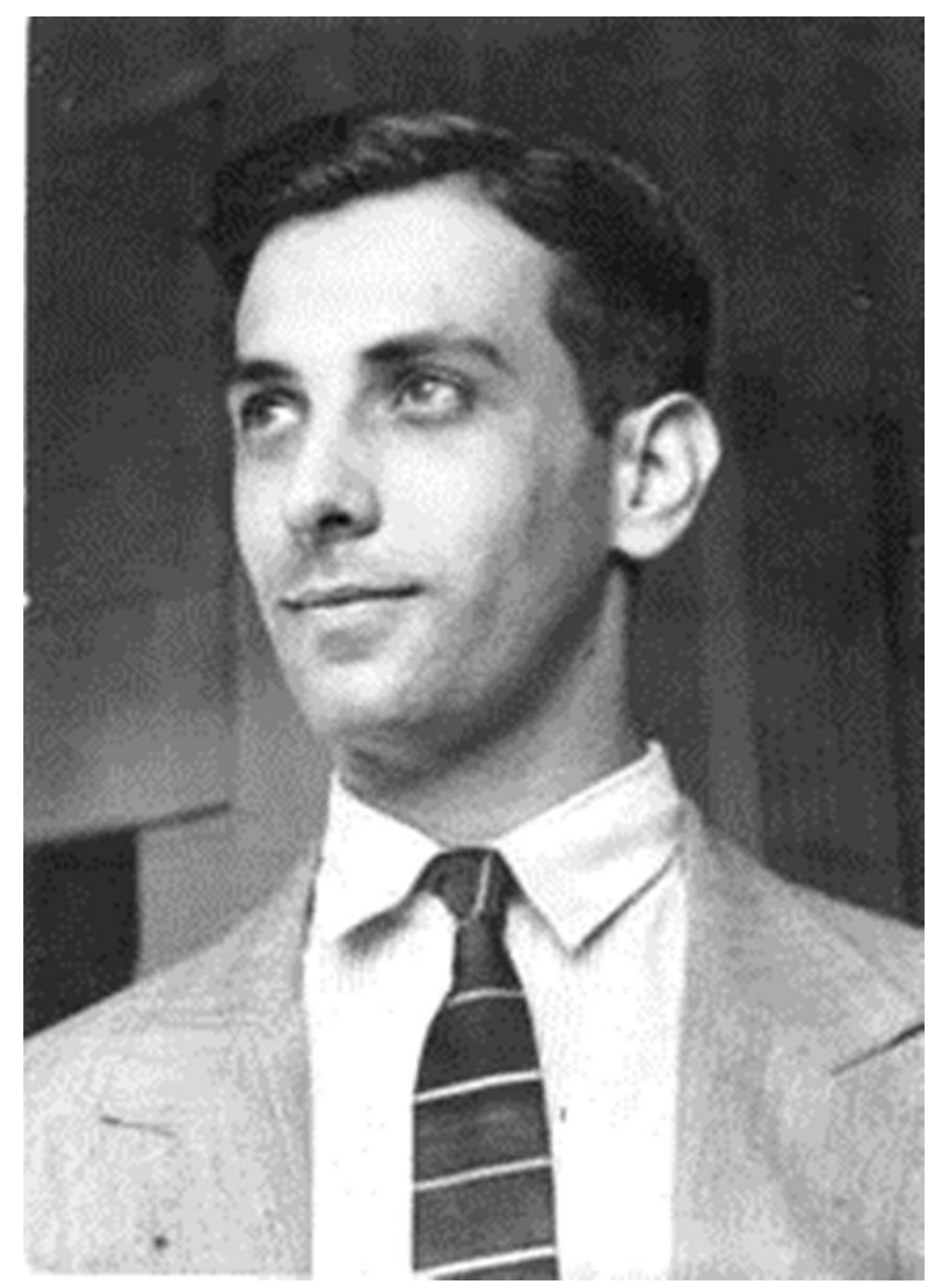

Lúcio Cardoso na juventude [década de 1930]

Acervo da família 


\section{júlio machado}

Quando me convidaram para o evento* que está na raiz dessa publicação, brinquei com os organizadores dizendo que cada releitura de Crônica da casa assassinada seria um retorno ao labirinto. O tom era de chiste, mas, como já sabemos desde Freud, Chaplin ou não importa quem, o chiste é coisa séria. O labirinto, então, podia bem servir como uma metáfora, mas de quê? Da sucessão infinita de corredores, alçapões e passagens secretas da província de Minas Gerais, a se confundir com o "sistema do senhor Demétrio", precariamente disposto sobre dois pilares pétreos: o orgulho de ter sido e a vergonha de já não ser. E, por derivação e para meu uso pessoal, da sucessão não menos infinita de corredores, alçapões e passagens secretas da mesma província de Minas Gerais, a se confundir com o sistema do senhor Manoel Machado Netto, meu avô materno, ainda mais precariamente disposto sobre dois pilares ainda mais pétreos: a vergonha de não ser e o orgulho de (nem) ter sido. E, veja-se: não o conheci em corpo, mas em sombra, já que ele, corpo, se foi antes que eu, também corpo, tivesse vindo. Mas pouco importa. Não circulam corpos pelo labirinto, apenas sombras, das quais tentamos, em vão, fugir. Não é difícil sair de uma província, de uma cidade, de uma casa, de uma família. Difícil é fazer com que eles, família, casa, cidade e província, saiam de nós. Eu quis me livrar de tudo e me perdi no labirinto. Segue o baile de sombras.

Júlio Machado (Júlio Cesar Machado de Paula) nasceu em Pouso Alegre, sul de Minas. Reside atualmente em Niterói e é professor de Literaturas Africanas na Universidade Federal Fluminense. Em poesia, recebeu, dentre outros, os prêmios Xerox/Livro Aberto, pelo livro $O$ itinerário dos óleos, e Nascente (USP/Editora Abril), pelo livro Mimnas. Publicou, em 2016, $O$ quintal e o mundo. Como dramaturgo, escreveu A profecia, para o Grupo Pândega, e Luzia, para o Teatro do Brejo Bento.

* O Colóquio Elegia Mineira: 60 anos da Crônica da casa assassinada foi realizado no dia 8 de novembro na Universidade Federal Fluminense, Rio de Janeiro, e no dia 22 de novembro na Universidade de São Paulo. 


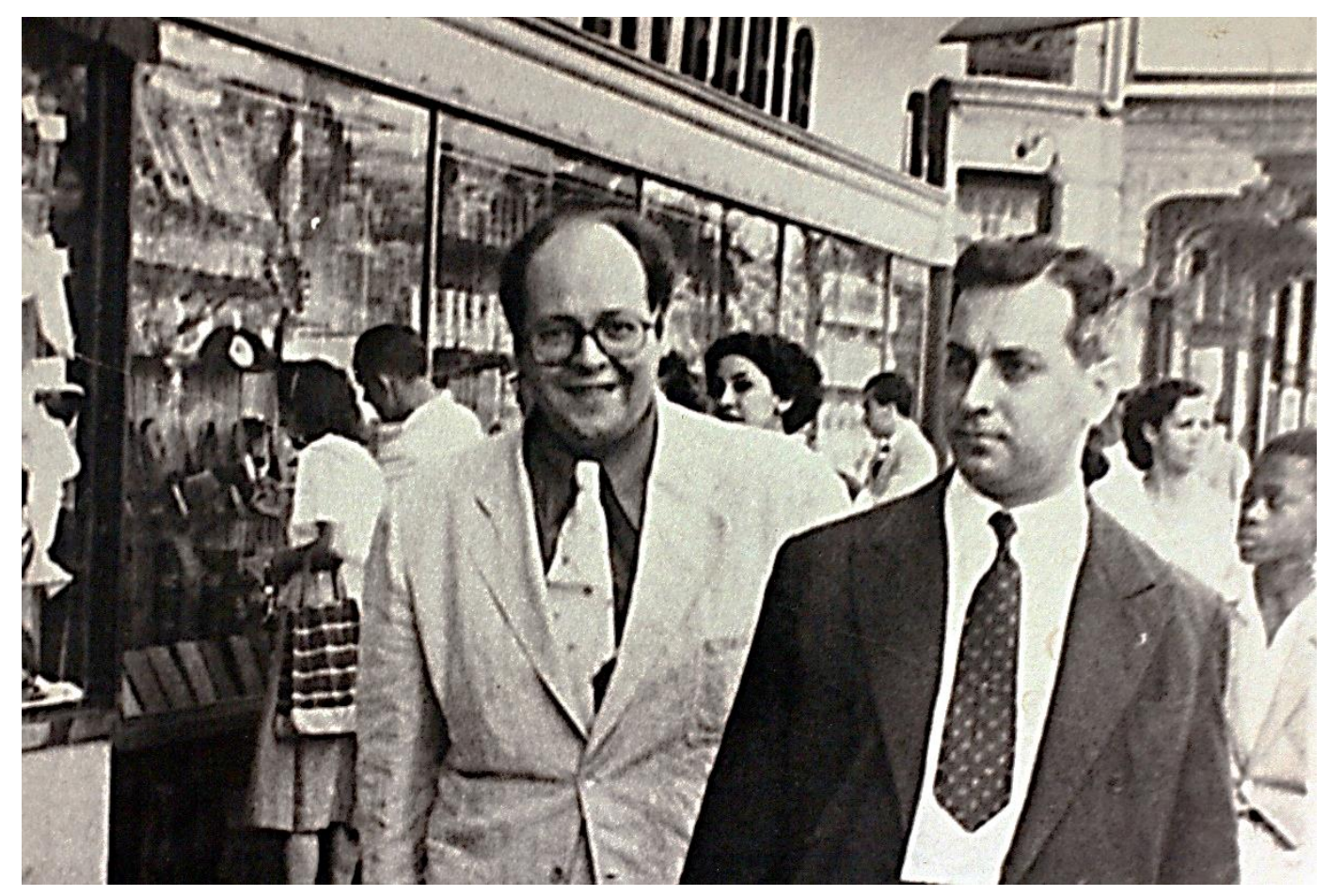

Lúcio Cardoso e Vito Pentagna (sem data). Acervo Luiz Carlos Lacerda 


\section{marcos antonio de moraes}

\section{[NOTAS DE UM DIÁRIO / “ARGUIÇÕES”]”}

[2020] “[...] Sua tese, Eduardo [Marinho], cumpre, com segurança, o procedimento hermenêutico em duas perspectivas, opostas e complementares: a primeira ambiciona compreender a estrutura do romance [Crônica da casa assassinada], a outra debruça-se sobre o miúdo, sobre as camadas da criação, as variantes do texto, percebidas nos manuscritos da obra. Você busca aliar crítica literária e crítica genética, para que a segunda amplie o conhecimento dos significados do texto ficcional. A observação do conjunto demanda um olhar sobre os nexos estruturantes da ficção, que realçam a figura de uma 'entidade' fantasmática que orquestra, que arranja, que ordena o enredo e nos enreda em suas tramas. No miúdo, a mão de Lúcio deixa marcas, traços, resíduos, que você quer recuperar, restituindo uma figuração no plano narrativo. Você se coloca (da mesma forma que essa personagem que deseja recuperar uma história perdida nas malhas do tempo e da memória) como um atento detetive. Ou melhor, um crítico perspicaz percorrendo do conjunto à unidade e desta àquele, em trânsito interpretativo potente."

[2019] “[...] No verbete 'casa' do Dicionário de símbolos de Jean Chevalier e Alain Gheerbrant, lemos logo na entrada: 'como a cidade, como o templo, a casa está no

\footnotetext{
Docente do Programa de Pós-Graduação em Literatura Brasileira e do Instituto de Estudos Brasileiros; membro da Equipe Mário de Andrade. É autor de Orgulho de jamais aconselhar: a epistolografia de Mário de Andrade (Edusp/Fapesp, 2007), e organizador das edições de correspondência: Correspondência Mário de Andrade \& Manuel Bandeira (Edusp/IEB, 2000), Mário, Otávio. Cartas de Mário de Andrade a Otávio Dias Leite (1936-1944) (IEB/Oficina Rubens Borba de Moraes/Imprensa Oficial, 2006), Câmara Cascudo e Mário de Andrade: cartas 1924-1944 (Global, 2010), dentre outras. E-mail: mamoraes@usp.br.

* Apresento trechos de minhas arguições em bancas de dissertações e teses focalizando a obra de Lúcio Cardoso, conservados em uns cadernos de notas. Eduardo Marinho da Silva. Trama íntima e figuração derradeira: o arranjador e a orquestração das vozes narrativas na Crônica da casa assassinada, de Lúcio Cardoso (2020, Universidade de São Paulo). Cleber Luis Dungue. Os espaços na prosa de Lúcio Cardoso (2019, Universidade de São Paulo). Daniel da Silva Moreira. Escritas de si e homossexualidade no Brasil: os diários de Lúcio Cardoso, Walmir Ayala e Harry Laus (2017, Universidade Federal de Juiz de Fora); Elizabeth da Penha Cardoso. Feminilidade e transgressão: uma leitura da prosa de Lúcio Cardoso (2010, Universidade de São Paulo).
} 


\section{opiniães}

centro do mundo, ela é a imagem do universo'; e mais adiante: 'a identificação do próprio corpo com a casa é corrente no Budismo'; e, ainda, linhas depois: 'a psicanálise reconhece, em particular nos sonhos de casa, diferenças de significação segundo as peças representadas, e correspondendo a diversos níveis da psique. $\mathrm{O}$ exterior da casa é a máscara ou a aparência do homem [...] os andares inferiores marcam o nível do inconsciente e dos instintos'. Sua tese, Cléber [Dungue], dedicada ao estudo do 'espaço narrativo' nos romances de Lúcio Cardoso, passa por essas trilhas e por outras muito ricas. Mostra-nos que a 'casa' (e suas representações) constitui-se o 'centro' de um imaginário ficcional, que esses espaços do viver tornam-se as 'argamassas' (p. 298) constitutivas dos personagens, e que por meio deles podemos aceder a abissais vivências internas, linha de força da criação de Lúcio Cardoso. Sob o signo da 'casa assassinada' você empreende um admirável percurso interpretativo. O seu percuciente trabalho crítico exigiu de mim uma leitura tensionada, sem sossego, para que eu não perdesse nenhum detalhe de sua argumentação tão precisa. A tese, de fato, me dou conta, tira o fôlego (assim como ficamos sem fôlego ao ler a prosa de Lúcio Cardoso), pela justeza das formulações críticas, pelas substanciosas conexões da literatura com outras artes e saberes, pela fluência e correção da linguagem, pelo domínio pleno de um estilo ensaístico autoral.”

[2017] “[...] Deparo-me, Daniel [Moreira], na página 295, quando a sua tese se volta para o tema do 'amor' testemunhado nos diários de Lúcio Cardoso, Walmir Ayala e Harry Laus, com esta curiosa formulação: 'não é de modo algum o caso dos meus diaristas'. Sublinho a palavra 'meus', que sugere instigantes leituras da sua relação com o seu trabalho intelectual. De fato, esses autores são objetos de sua pesquisa, mas essa relação não parece ser simplesmente intelectual. São 'seus' diaristas, não apenas porque fornecem matéria para o desenvolvimento de uma tese, mas porque são capazes de atribuir um significado muito maior para quem sobre eles se debruçou com tanta dedicação. Estou refletindo aqui sobre os vínculos entre o pesquisador Daniel e as escritas memorialísticas de três diaristas que ele ostensivamente admira. Longe de mim estar aludindo a qualquer tipo de projeção pessoal que resultaria, ao fim e ao cabo, no emparedamento da prática hermenêutica, levando o crítico a produzir unicamente um gesto de engajamento (embora isso, em tantos contextos, também tenha a sua importância), mas a um tipo de vínculo afetivo, de natureza produtiva, capaz de iluminar o profundo sentido humano que perpassa as escritas desses diaristas. Em suma, é visível em sua tese a 'paixão' pelo conhecimento, ao se aprofundar, com respeito e compromisso intelectual, na experiência dessas vidas exemplares. Poucas vezes 
tenho visto, em teses na área do memorialismo, uma ligação tão fecunda, entre observador e seus objetos. São, realmente, Daniel, 'seus diaristas', mas não há possessividade nessa afirmação, pois você não se nega a partilhar o seu conhecimento densamente esclarecedor sobre eles. A sua interpretação dos diários representa uma partilha generosa de um saber conquistado. Você e seus diaristas são, agora, 'nossos'.”

[2010] [...] "Percebo, Elizabeth [da Penha Cardoso], a sua grande capacidade de visualizar a obra ficcional de Lúcio Cardoso em uma totalidade, dirigindo o olhar para a complexa rede de personagens criada pelo autor, para realçar os seus vínculos e significados. Noto, ainda, em sua tese, a apreensão consistente da visão de mundo do autor e de sua concepção estética. Destaco o seu conhecimento seguro da fortuna crítica de Lúcio; e o seu (Elizabeth) vigoroso esforço de ir na contramão de algumas proposições críticas, refutando aquilo que à primeira vista parece fragilidade ficcional, munida do aparelhamento teórico da psicanálise. [...] Você levanta, de modo oportuno, a problemática do gênero [discursivo] na obra ficcional de Lúcio Cardoso, ao discutir a caracterização de 'novela' e 'romance', fixada pelo próprio autor, e a dificuldade em conceber uma definição clara sobre essa diferenciação. Você afirma na página 42 que é 'difícil estabelecer os parâmetros que o levaram a classificar os gêneros de seus textos'. Você acha que essa classificação interfere no trabalho de interpretação da obra? Ou são termos permutáveis? [...]. As personagens femininas de Lúcio que você estudou com argúcia (Ida, Stela, Nina e Ana), inquietas e transgressoras, são punidas (explicitamente ou apenas em termos de sugestão) com a morte. Você acha que seria possível associar morte e direcionamento moral nas narrativas estudadas em sua tese?” 




Lúcio Cardoso (1912-1968). Músicos, pastel sobre papel, $60 \times 90 \mathrm{~cm}$. Assinado no c.i.e., s/d [1966]. Coleção Ésio Macedo Ribeiro 


\section{leandro garcia rodrigues}

\section{UMA CRÔNICA DE EMOÇÕES ESTRANHAS...}

A primeira vez que a Crônica chegou às minhas mãos eu tinha 19 anos, estava no primeiro período do curso de Letras, na Universidade Castelo Branco, subúrbio do Rio. Foi-me indicada por um professor de literatura inglesa, o Leonardo Mendes, que disse: "Você não será mais o mesmo depois de ler este livro". De fato, o Leo estava certo, sofri durante a leitura e nunca mais fui o mesmo em termos de cabeça, de sentimentos, de visão da vida, de impacto produtivo que uma obra literária me despertou.

Para um jovem estudante de Letras, nascido e criado na periferia carioca, de família exageradamente católica e até piegas, ler e sentir aquela paixão entre Nina e André, aquele incesto até necessário, aquela espécie de submissão à paixão, a lei forte do amor... tudo isso se me abateu deveras...

E o que dizer de Timóteo, aquele ser híbrido, num entre-lugar existencial, sensível, apaixonado de amor visceral, meio andrógeno, homem e mulher ao mesmo tempo...? Timóteo me deu uma baita porrada na minha moralzinha baixa de católico praticante. O que fazer com Timóteo? Como ler Timóteo? Onde pôr Timóteo na minha própria vida após aquela leitura? O que fazer com toda aquela perversão: tornar-me eu próprio um pervertido?

De fato, meu professor estava certo: nunca mais fui o mesmo após aquela primeira leitura da Crônica, bem como sofri outra porrada anos depois, quando reli o mesmo livro, já lecionando numa graduação em Letras.

\footnotetext{
Leandro Garcia Rodrigues é Doutor e Pós-doutor em Estudos Literários pela PUC-Rio e Pósdoutor em Teologia pela Faculdade Jesuíta de Filosofia e Teologia de Belo Horizonte. Professor Adjunto II de Teoria Literária e Literatura Comparada da Faculdade de Letras da UFMG; pesquisador do CNPq e pesquisador do Museu Imperial de Petrópolis (RJ). Organizou o livro Lúcio Cardoso: 50 anos depois (Relicário, 2020), além de outras edições, como Alceu \& Drummond (Editora da UFMG, 2014), Cartas de esperança em tempos de ditadura (Vozes, 2015) e Correspondência Mário de Andrade \& Alceu Amoroso Lima (Edusp/PUC-Rio, 2018). Email: prof.leandrogarcia@hotmail.com. ORCiD: https://orcid.org/0000-0002-7316-890X.
} 


\section{opiniães}

Não entendo que força era essa que Lúcio Cardoso tinha! Que capacidade foi a sua de penetrar o sensível e nos revirar por dentro, nos forçando a vomitar os nossos males e preconceitos, a nossa formação conservadora. Lúcio devia ter um demônio dentro de si que se revoltava sempre, um demônio que o obrigava a despertar os nossos próprios demônios, causando a perigosa náusea que Sartre tanto nos preveniu, disso tenho certeza.

Há exatos 25 anos eu li a Crônica pela primeira vez - 25 anos! Era o começo de 1995, era o início dos meus estudos de literatura, era o começo de um certo malestar que me dura até hoje... 
Dirão que isto talvez não passasse de impressão exagerada, mas a verdade é que de há muito eu pressentia um mal qualquer devorando os alicerces da Chácara. Aquele reduto, que desde a minha infância - há quanto tempo, quando a estrada principal ainda se apertava entre ricos vinháticos e pés de aroeira, tortuosa, cheia de brejos e de ciladas, um prêmio quase para quem se aventurasse tão longe... - eu aprendera a respeitar e a admirar como um monumento de tenacidade, agora surgia vulnerável aos meus olhos, frágil ante a destruição próxima, como um corpo gangrenado que se abre ao fluxo dos próprios venenos que traz no sangue. (Ah, esta imagem de gangrena, quantas vezes teria de voltar a ela - não agora, mais tarde - a fim de explicar o que eu sentia, e o drama que se desenrolava em torno de mim. Gangrena, carne desfeita, arroxeada e sem serventia, por onde o sangue já não circula, e a força se esvai, delatando a pobreza do tecido e essa eloquente miséria da carne humana. Veias em fúria, escravizadas à alucinação de um outro ser oculto e monstruoso que habita a composição final de nossa trama, famélico e desregrado, erguendo ao longo do terreno vencido os esteios escarlates de sua vitória mortal e purulenta).

Segunda narrativa do médico. Crônica da casa assassinada. Lúcio Cardoso. 


\section{opiniães}

\section{simone rossinetti rufinoni}

\section{UM ROMANCE VERTIGINOSO*}

A que se deve a sensação de vertigem que se desprende da leitura da Crônica da casa assassinada, de Lúcio Cardoso? A resposta talvez resida na relação entre duas forças antagônicas atuando na composição da obra: a ânsia de liberdade expressa pelo desdobrar obsedante da autoanálise - e a opressão do meio traduzida pela presença da casa-família-tradição. Tais polos entrecruzam-se ao longo da intriga que, por sua vez, desdobra uma série de contrários: liberdade e coerção, desejo e castração, transgressão e culpa. Latente, em meio às vozes e à ruína da casa, pulsa a promessa da modernidade contra a permanência do velho código senhorial.

A duplicidade entre os relatos do eu e a prisão da casa reflete-se na fatura cujo caráter epistolar, ao mesmo tempo em que aposta na amplitude da reflexão introspectiva, condena todos à armadilha da incomunicabilidade - a composição reúne os fragmentos, mas estes não se dão a ler uns aos outros. Advém daí certa loquacidade histriônica que, associada à interdição da interpessoalidade e ao emudecimento, dá ao romance um tom singular de exaltação impotente, como se a licença e inviolabilidade das páginas íntimas se desfizesse ante a autoridade do meio e da família. De modo que a potência da fala, do desejo e do desejo da fala é constantemente deslegitimada pela autoridade patriarcal. Sabe-se, contudo, que a opressora e decadente casa-grande está condenada, que sua derrocada avança a cada passo. Não é à toa que a casa assassinada ecoa o corpo em decomposição de Nina, a grande inimiga dos Meneses e da tradição.

Nesse sentido, a voragem que emana do romance assume o aspecto de um coro de vozes em disputa, cujo clamor se dirige à busca pela individuação - à luta em surdina pela existência fora do controle do grupo parental - constantemente

\footnotetext{
* Professora de Literatura Brasileira na Universidade de São Paulo, autora de Favor e melancolia: estudo sobre A menina morta, de Cornélio Penna (Edusp/ Nankin, 2010) e organizadora de Caminhos da lírica brasileira contemporânea: ensaios (Nankin, 2013). E-mail: siruf@hotmail.com. ORCiD: https://orcid.org/0000-0002-7915-8913.
} 
coibida e minada. Para desencadear a destruição, a heroína dissemina sua arma: eros que se faz palavra.

Pode-se supor que, em alguma medida, o todo da composição, urdidura de vozes que gritam sua sede de vida e expansão, reverbera a pressão e imponência da chácara dos Meneses; no entanto, o romance, na contramão da grande propriedade, concentra e organiza o impulso à vida por meio do exercício do discurso e do corpo insubmissos.

Se as vozes encontram na escrita de si canal possível de emancipação, a literatura parece confiar à construção dialética das vozes encarceradas o poder de abalar um sistema obsoleto. Assim, caberá à organização estética simular as vozes - cartas, diários, confissões - que, tornadas literatura - o romance como potência maior da escrita -, perfazem-se estrutura de resistência, força capaz de minar os alicerces da casa-país. 


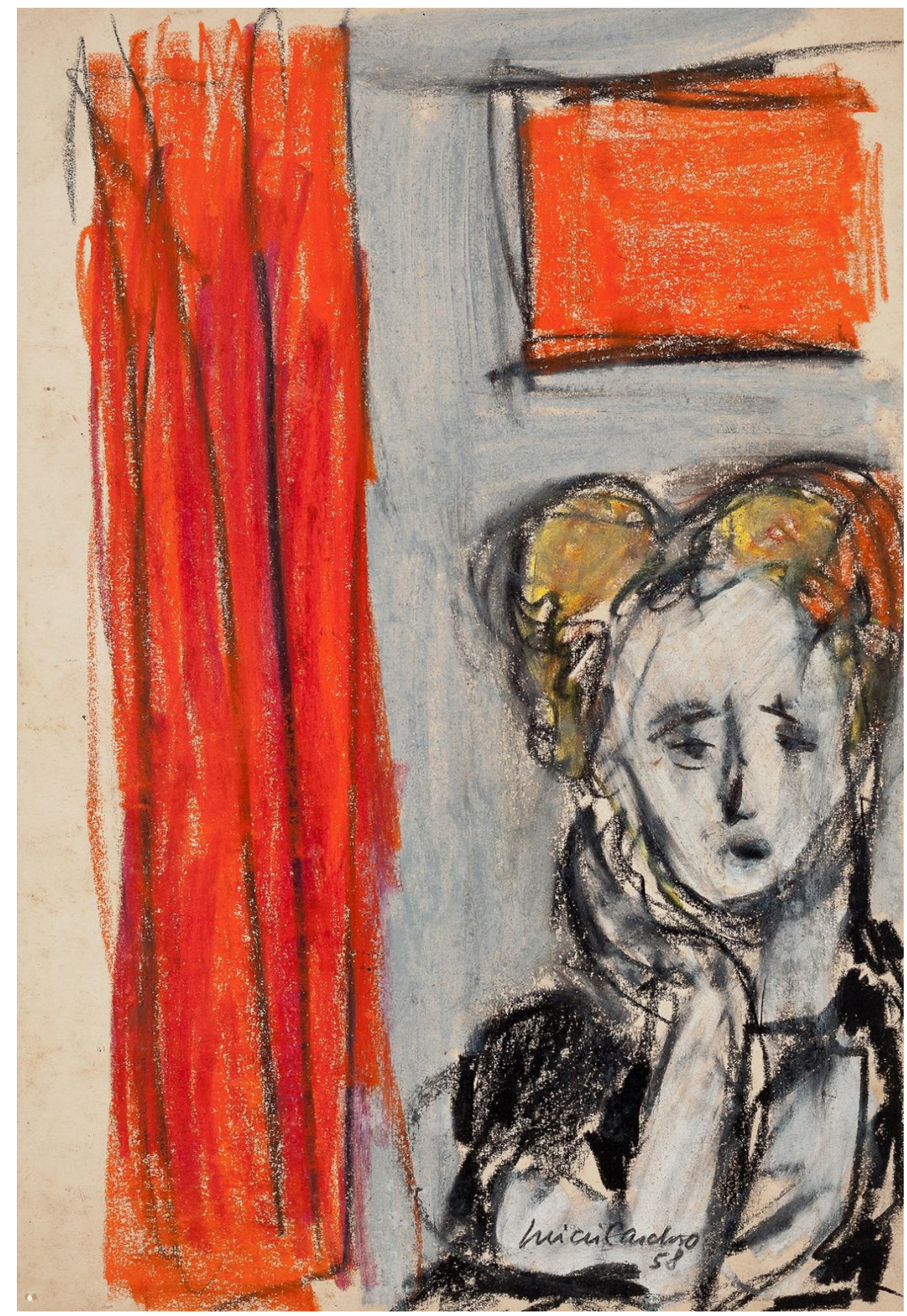

Lúcio Cardoso (1912-1968). Sem título, pastel sobre papel. Assinado no c.i.d. (1958). Acervo particular 


\section{nádia degrazia}

Às primeiras páginas, muito mal estar. Vontade de não prosseguir. O romance se inicia com o relato de André, perplexo, no leito de morte de sua amante-mãe. Em original junção de palavras, ele diz: "O para sempre ali se achava diante dos meus olhos”. A dureza da perda e a irreversibilidade do tempo. Para o jovem André, só resta escrever sobre o vivido, naquele amor secreto e transgressor.

Não sei se teria continuado sem a recomendação de amigo para a leitura e sem conhecimento dos elogios de outros grandes escritores brasileiros. Para escrever essas linhas, fui reler o livro, decorridos dois anos da primeira leitura. Dessa vez, gosto mais e a leitura flui melhor, embora desconfie que um livro contado por muitos dificulte um tipo de conforto que pode ser obtido, quando há apenas um narrador, com uma pretensa única verdade. Verdade absoluta, por vezes tão essencial, como Timóteo fala à Betty. Como na vida, não há uma só versão e nunca é fácil o convívio com verdades parciais.

E, de tantos pensamentos que surgiram durante a leitura, seleciono por fim falar apenas do efeito em mim dos escritos de André, em seus diários. A impressão da destruição psíquica de André nesse seu curto tempo de vida. E aí, já mergulhada na trama, tomo partido e odeio Nina. Por que ela deixou que André acreditasse que era seu filho? Para deixá-lo aprisionado na situação incestuosa, como nós, leitores, ficamos da primeira página até o final, enfeitiçados por sua sedução? Ele foi assassinado em vida, mais do que a casa.

Em trechos de "Confissões de um homem fora do tempo", pinçados por André Seffrin no prefácio de uma edição do livro ora comentado, Lúcio Cardoso diz que acredita no romance "que é feito com sangue, [...] no que foi criado com as vísceras, os ossos, o corpo inteiro, o desespero e a alma doente do seu autor [...]". Parece, realmente, que assim foi escrita a Crônica da casa assassinada.

Nádia Degrazia Ribeiro é psicanalista membro do Tempo Freudiano Associação Psicanalítica, no Rio de Janeiro. No serviço público, atuou como psicóloga na área da saúde municipal em Duque de Caxias (RJ) e no sistema prisional do Estado do Rio de Janeiro. Possui mestrado em Psicologia Clínica (PUC-Rio), com dissertação sobre a correspondência amorosa na prisão. 


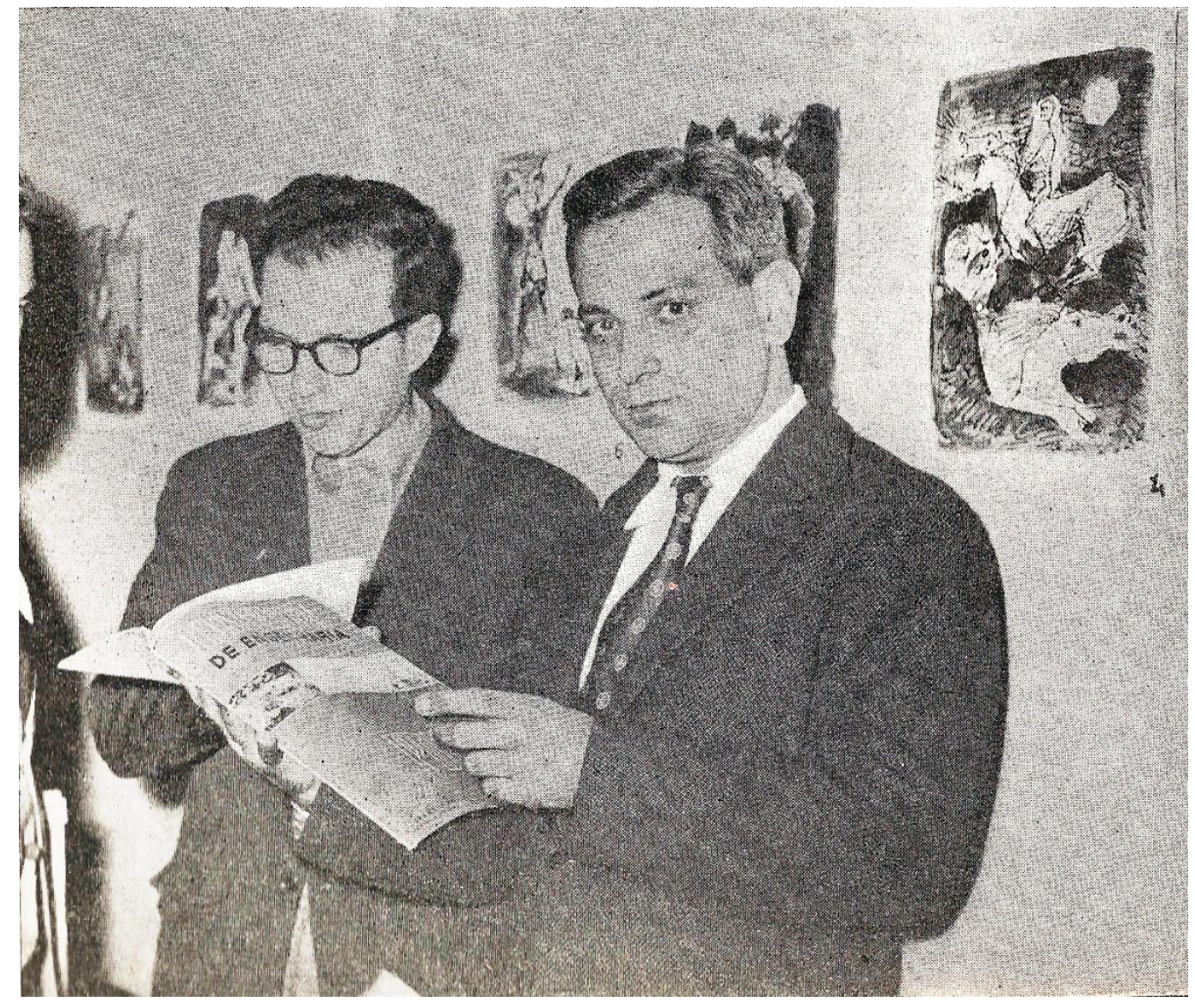

Lúcio Cardoso em vernissage de Darel Valença Lins. Fotografia de Raul Penedo para A Noite [década de 1960]. Acervo da família 


\section{thais gomes}

Há essa impressão de que nossa última leitura talvez seja a que mais nos reverbera memórias intensas. Estremece-se ainda o corpo que se lembra das afiadas descrições sobre a personagem Nina, que com toda sua beleza e contradição nos permitiu imaginar e sentir, através de cada palavra.

Relatar o que se passa no campo das sensações ao ler Crônica da casa assassinada não é tarefa fácil, percorre o indizível. Entre piedades espontâneas, desconfortos indesviáveis, relatos de paixões vivas, foi tudo remexido ao fundo, a cada capítulo, a cada indagação que nos pegamos fazendo.

Ao que remete aos assombros do texto, não é possível deter-se em tentar decifrar Timóteo e Maria Sinhá, personagens presas na monstruosidade de serem verdades para si mesmas. Destacam-se como mistérios, pela impossibilidade na escrita aberta sobre o tema que atordoa a vida do autor também, a homossexualidade.

Crônica da casa assassinada encontra confusões que dialogam com o intrínseco. Seja pelo toque quase discreto no tabu ou pelo desencontro de acontecimentos, forçando a dúvida para o limite.

A sensibilidade passada pelos pensamentos de André, as narrativas cativantes de Betty, a importância de personagens como Alberto para o véu da trama, tudo em um emaranhado que transporta o leitor para os dias tipicamente quentes do interior de Minas, mais precisamente, levam à casa assassinada.

Thais Gomes, nascida em Juiz de Fora (MG), é estudante de graduação em LetrasPortuguês/Francês, na Universidade Federal Fluminense, professora e musicista. 
Chegava a rodar, a ensaiar um passo de valsa; acordes invisíveis faziam soar acima da minha cabeça uma música de vitória, e eu girava como se estivesse embriagada, e comigo girava a paisagem naquela primeira e única dança em que eu deixava extravasar toda a alegria do meu ser. Se alguém me visse, pensaria por certo que eu tivesse enlouquecido - e não estaria longe da verdade, pois a alegria do solitário é como uma taça de champanha brutalmente sorvida: altera de imediato os sentidos, e produz uma efervescência que muito se assemelha à dos que não controlam mais o espírito. Se alguém me visse, pensaria por certo que eu tivesse enlouquecido e não estaria longe da verdade, pois a alegria do solitário é como uma taça de champanha brutalmente sorvida: altera de imediato os senti dos. e produz uma efervescência que muito se assemelha à dos que não controlam mais o próprio espírito. Não sei quanto tempo girei assim no escuro, abraçada àquele fantasma elaborado com os lençóis amarfanhados - sei apenas que rodei, rodei, enquanto sentia subir-me às narinas um odor forte de violetas e heliotrópios esmagados, como o que se desprende de uma gaveta onde existem guardadas velhas roupas de baile. Finalmente, esfalfada, abati-me junto à coluna do tanque, ofegante, a testa molhada de suor. A trouxa escorregou-me das mãos. Durante algum tempo, imóvel, permaneci como rosto colado junto ao cimento frio. Deus existia, repetia comigo mesma, pelo menos o Deus inflexível e capaz de desferir o raio, mesmo sobre os mais diletos objetos de sua criação - mesmo sobre aqueles que, como Nina, houvessem no seu acúmulo de graça infringido as severas leis a que são submetidos todos os seres humanos. Agora poderia vagar tranquila, pois tinha certeza de que Deus me ouvia e não se desinteressava da pobreza dos meus gestos. Meu espanto nada tinha a ver com a ferocidade do decreto. $E$ isto me transmitia - afinal - uma paz seca, sem nuanças e também sem alegria. Sobre aquele último passo de dança, o que eu gozava era o sossego da missão terminada. 


\section{alexandre siqueira}

DOENÇA CRÔNICA

A casa dos Meneses tem o peso gélido das gerações que lá viveram, desde os dias de glória à óbvia decrepitude. Os que nela agora habitam são os sucessores, os depositários do patrimônio, os guardiões. Cumpre-lhes ocultar tudo o que ali se desvia do código imemorial de que são os derradeiros portadores. Assim, também, sua linguagem enturva os sentidos, sugere o não dito, o maldito. Todo desejo fica interdito.

A insipidez, a falta de graça, a solidão dos dias e das noites, tudo sofre desmedido transtorno quando na casa se estabelece uma nova presença - o inferno à espreita, quantas ameaças! A beatitude do nada não cede: reivindica seus direitos. Dá-se a conjura, ceifa-se a exuberante planta exótica.

Eis que, de raízes supostamente não extirpadas, brota um novo ramo, ao qual os Meneses dedicam intensos cuidados de condução aos moldes da ordem de sempre. Mas uma irremediável flor irrompe, exalando um aroma que a ninguém deixa indiferente. Por tanto tempo represado, o desvario precipita-se e a vida impregnada naquela casa e em seus objetos se esvai. Requiescat in pace. Depois de eras, o caos retoma seus domínios usurpados.

Alexandre Siqueira, paulistano, vive no Rio desde 1980. Como engenheiro, já aposentado. Como apaixonado leitor, ainda na ativa. 


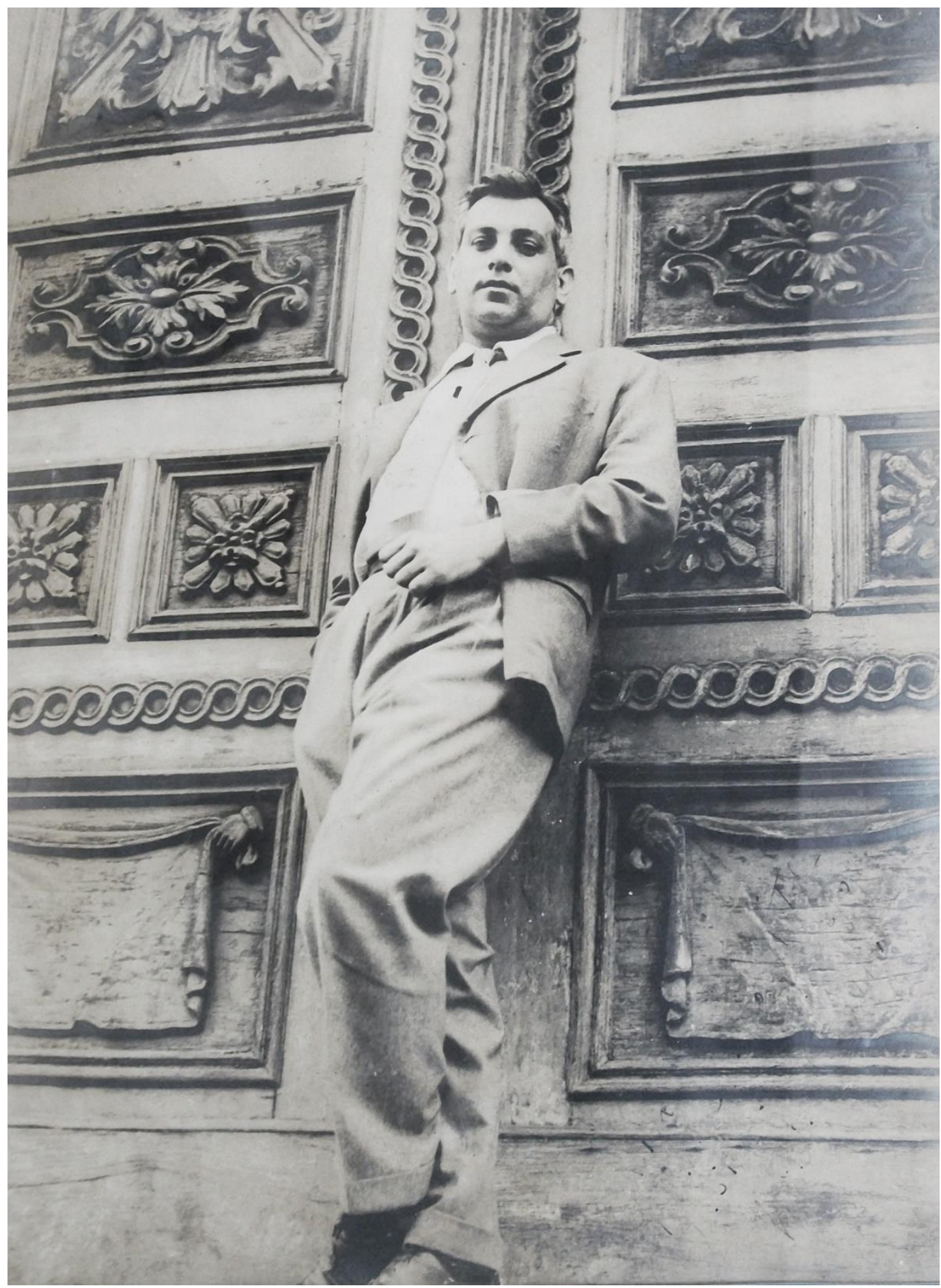

Lúcio Cardoso. Fotografia de Jayme Acioli [1958]. Acervo da família 


\title{
andrea vilela
}

\section{OS RUÍDOS DO SILÊNCIO}

A meio século da publicação desse que tem sido considerado um dos mais fundamentais romances da literatura brasileira, releio um dos trechos do Diário de Lúcio Cardoso, escrito às vésperas do seu lançamento:

\begin{abstract}
Um jornal publica hoje a capa do meu livro a sair no mês próximo. Dois anos, e mesmo assim, menos tempo do que levei para publicar $O$ enfeitiçado, que durante tanto tempo rolou em minhas gavetas. Mas apesar disto, é o suficiente para que eu perceba os defeitos da Crônica e avalie os lados onde envelheceu. Isto me consola, imaginando que possa fazer melhor. Mas assalta-me uma grande melancolia, imaginando que também este tombará no silêncio e no desinteresse e que, independente de seus defeitos, que talvez só eu conheça, poderia ser uma obra prima que encontraria a mesma repulsa e a mesma prevenção que vêm encontrando todos os meus outros livros...
\end{abstract}

Nesse desabafo escrito, Lúcio se mostra desiludido em relação à recepção de sua obra, mas revela, também, seu espírito inquieto e a plena consciência do seu valor. Talvez seja possível pensar na Crônica como uma metáfora de sua obra, configurada por partes envolvidas por pausas e silêncios em que são encaixados seus escritos, num mosaico em que cada parte, vista de perto, dá a impressão de ser uma pedra colorida lavrada em formato quadrado, porém, ao se mudar a perspectiva e manter distanciamento, percebe-se se tratar de uma imagem configurada pela montagem de partes cuidadosamente encaixadas a formar um todo. Um rosto sagrado, talvez. Imagem e semelhança de um criador de atmosferas que jamais se deixou estagnar pelo repouso dos apaziguados. A obra de Lúcio o mantém vivo, com seus olhos de corcel de fogo a penetrar os porões das nossas almas atormentadas pela existência de seres incompletos. Mosaicos humanos em busca das partes com as quais construiremos nós, também, a nossa própria face. Viva Lúcio Cardoso!

Andrea Vilela, sobrinha-neta de Lúcio Cardoso, é professora e pesquisadora da Escola de Belas Artes da Universidade Federal de Minas Gerais (UFMG). Realizou seu mestrado e seu doutorado na Faculdade de Letras (FALE) da UFMG, produzindo a dissertação "Olhar sobre uma Casa Escrita - A poética de Lúcio Cardoso no romance Crônica da Casa Assassinada" (2001) e a tese "Lúcio Cardoso - 0 traçado de uma vida" (2007).

* Assim Clarice Lispector designou Lúcio Cardoso numa crônica que escreveu em sua homenagem, para o Jornal do Brasil, em 1969. 




Lúcio Cardoso (1912-1968). Figuras, técnica mista sobre papel, 45 x 30,5 cm. Sem assinatura, s/d. Coleção Ésio Macedo Ribeiro 


\section{maroaret jull costa e robin patterson}

Chad Post of Open Letter Books got in touch with me (Margaret) to ask if I would be interested in translating Crônica da casa assassinada. I had never heard of the book or the author. When I read it, however, I knew at once that I wanted to translate it, but that I would also like to have company on the way! It was then that I got in touch with Robin, my co-translator, who, happily, agreed to be my translating companion. Deciding how to divide up the book proved very easy. I (with one exception, namely André) would translate the female narrators, and Robin would translate the male ones. This was not some gender-specific division (after all, I have translated as many male authors as female ones), but simply to help in the process of differentiating the various narrators' voices, and, at a more basic level, because this happened to provide us each with a similar number of pages. We translated our designated chapters, then swapped over to read and edit each other's, and I do think that, in the translation, each narrator does have his or her own voice, which is, of course, the great strength of the novel itself. It really is a chorus, each narrator having his or her own say about the events leading up to the demise of that decaying house and family. "Decay" is probably the key word. Never have death and putrefaction (both literal and metaphorical) been described in such unflinching detail. I think we are both haunted by certain scenes, as if the stench from Nina's slowly rotting body still lingered in the air. This is a completely original work in so many ways, and for which there is no real equivalent in the English-language canon - or perhaps in any other.

Margaret Jull Costa é tradutora de poesia e ficção de línguas portuguesa e espanhola para o inglês. Já traduziu trabalhos de José Saramago, Eça de Queiroz, Fernando Pessoa e Javier Marías. Sua tradução para o inglês do romance Crônica da casa assassinada [Chronicle of the Murdered House], feita em 2016 em parceria com Robin Patterson para a editora Open Letter Books, recebeu o prêmio Best Translated Book Awards do ano de 2017.

Robin Patterson, é tradutor de ficção e poesia de línguas portuguesa e espanhola para o inglês (já tendo traduzido José Luandino Vieira), tem realizado diversas traduções em parceria com Margaret Jull Costa, entre elas a premiada Crônica da casa assassinada [Chronicle of the Murdered House], de 2016. 


\section{opiniães}

O Chad Post do Open Letter Books entrou em contato comigo (Margaret) para saber se eu tinha interesse em traduzir a Crônica da casa assassinada. Eu nunca tinha ouvido falar do livro ou do autor. Quando o li, no entanto, eu soube de imediato que eu queria traduzi-lo, mas também gostaria de ter companhia neste processo! Foi aí que entrei em contato com Robin, meu co-tradutor, que alegremente concordou em ser minha companhia na tradução. Decidir como seria a divisão das traduções se mostrou muito fácil. Eu traduziria as narradoras femininas (com uma exceção, André), e Robin traduziria os narradores masculinos. Não se tratava de uma divisão por gênero especificamente (afinal, já traduzi tanto autores homens quanto mulheres), mas simplesmente por ajudar no processo de diferenciação das várias vozes dos narradores, e, num nível mais básico, porque assim nos forneceria um número similar de páginas. Nós traduzimos nossos capítulos designados, depois trocamos para ler e editar um ao outro, e eu acho que, na tradução, cada narrador tem sua voz própria, o que é, certamente, a grande força do próprio romance. É realmente um coro, cada narrador tendo sua própria opinião sobre os eventos que levaram à decadência daquela casa e família. "Decadência" é provavelmente a palavra-chave. Nunca a morte, a putrefação (ambas literais e metafóricas) foram descritas com tantos detalhes inabaláveis. Acho que nós dois estamos assombrados por certas cenas, como se o fedor do corpo de Nina apodrecendo lentamente ainda pairasse no ar. Esta é uma obra completamente original de tantos modos, e para a qual não há equivalente no cânone de língua inglesa - ou talvez em nenhum outro.

Tradução de Érica Ignácio da Costa 


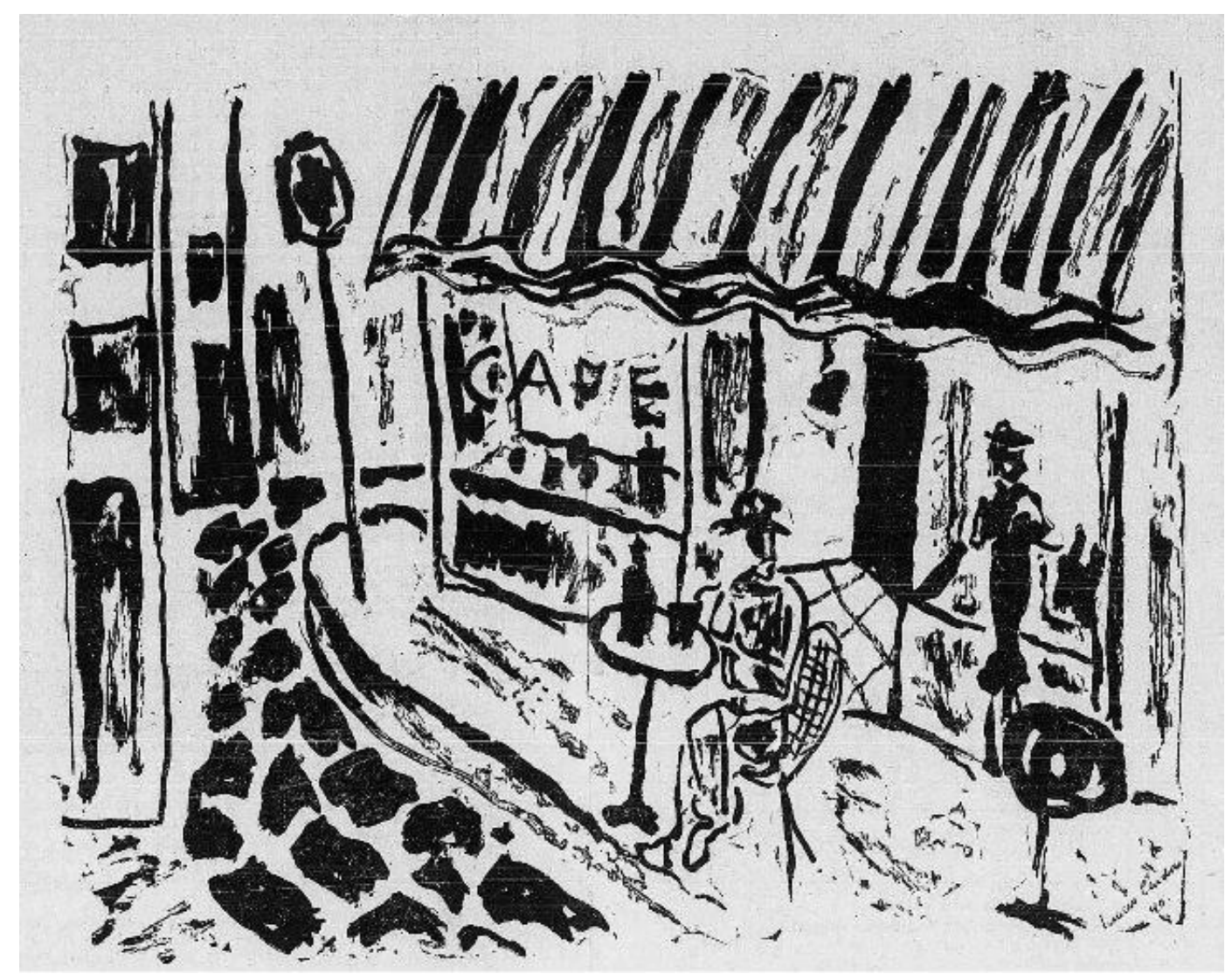

Lúcio Cardoso (1912-1968). Café [1946]

Coleção particular. 


\section{opiniães}

\section{narrie lemmens}

\section{VOZES}

Esse título! Que título espantoso! Crônica da casa assassinada. Uma casa que ganha vida para poder ser assassinada. Ao mesmo tempo personagem e cenário. Conhecia o livro através de artigos e histórias de outras pessoas quando, em 2005, decidi comprar e ler a bela edição da Civilização Brasileira. A morte abre e fecha este romance polifônico de que o escritor precisava para se livrar do sufoco de Minas Gerais.

Não foi esse o meu primeiro contato com Minas Gerais. Nem com uma casa com um papel tão central. Em 1997, traduzi a Ópera dos Mortos, de Autran Dourado, que também se passa numa cidade do interior, também numa casa onde a vida tal como o relógio - parou e que é habitada por vozes que narram a história. Tal como o coro de uma tragédia grega ou de uma ópera italiana. Opressivo, impressionante, grandioso.

Estes três atributos aplicam-se perfeitamente à Crônica. Trata-se aqui de uma vibrante literatura de libertação, em grande parte, como não podia deixar de ser, autobiográfica. Tudo parece não só uma realidade romanesca, mas também simbólica. É uma viagem, por vezes tresloucada, pelo inferno a que se dá o nome de tradição. Uma tradição que manieta o ser humano dentro de um espartilho ou de uma camisa de forças, de que apenas se pode desenvencilhar por uma rebeldia pecadora que tudo esfrangalha.

Que o Brasil não é só o país do futebol, do carnaval e de outros divertimentos exuberantes, já eu tinha aprendido graças à obra do outro grande escritor brasileiro (falecido, tal como Autran Dourado, na última década), João Ubaldo Ribeiro. Sim, é verdade, ele cultiva o riso nos sete livros que traduzi, mas nunca esquece o reverso da medalha, não esquece que a alegria esfuziante não é mais do

Tradutor e escritor, Harrie Lemmens verteu para o holandês diversos autores da comunidade lusófona, como António Lobo Antunes, Autran Dourado, Fernando Pessoa, João Ubaldo Ribeiro, José Saramago, Machado de Assis, Mia Couto, dentre outros. É autor de Deus é brasileiro (Zouk, 2015). Atualmente, prepara a tradução da Crônica da casa assassinada para o holandês, a ser publicada em 2021 pela editora Arbeiderspers. www.harrielemmens.nl. 
que uma máscara da suprema tristeza. As vozes que na sua obra sussurram, cantam e gritam são uma inegável expressão dessa realidade.

Numa foto da minha esposa, a fotógrafa portuguesa Ana Carvalho, incluída no meu livro Deus é brasileiro, vê-se uma parada de ônibus em Belo Horizonte onde quatro pessoas estáticas e sombrias estão esperando. Ocorreu-me essa imagem quando li na Crônica este suspiro de André: "Não há tempo para mim, nem passado e nem futuro, tudo é feito de irremediável permanência. $\mathrm{O}$ inferno é assim - um espaço branco sem fronteiras no tempo".

Em contraste com a monotonia esmagadora dessa casa sinistra, Lúcio Cardoso coloca a frivolidade irrequieta de Nina, a intrusa, aquela que, vinda da cidade grande, que é o Rio, entra de assalto no mundo rural da Chácara onde desencadeia uma autêntica revolução, cujos protagonistas são o seu filho André e a sua cunhada Ana. Esta livra-se figurativamente da sua eterna roupa de luto e o André quase volta literalmente para o útero, pela relação que mantém com a mãe.

Em 2016 traduzi Lavoura arcaica de Raduan Nassar, em que o protagonista (André!) foge da casa que lhe corta o caminho para a liberdade. E ele também se perde loucamente num amor incestuoso - com a irmã que, no final, quando o filho pródigo retorna a casa, é assassinada pelas mãos do seu pai: aqui, no interior de São Paulo, é a casa que vence. Com Lúcio Cardoso a casa vai-se desmoronando a pouco e pouco.

Senti que tinha de traduzir esse livro e falei com várias editoras, mas só uns anos atrás consegui uma reação positiva da Arbeiderspers. E finalmente, em 2021, este clássico vai sair também em Neerlandês.

E é difícil de traduzir? Sim, claro que é, mas uma tal diversidade, vozes cada uma delas com timbre, vocabulário e sintaxe diferentes, frases por vezes longuíssimas que mais pode desejar um tradutor?

Como acontece tantas vezes, o inferno nos livros é o paraíso para a minha profissão. 
(Aqui paro um momento, é evocando sua própria visão [de Nina] que indago: que é a beleza? A beleza é uma destinação de nossos fluidos íntimos, um êxtase secreto, um afinamento entre o mundo interior e a existência cá fora. Um dom de harmonia, se assim posso me exprimir. Nina jamais se destacou de um ambiente, qualquer que ele fosse compunham, com essa simplicidade dos seres inocentes, a quem foram atribuídas todas as graças). Desde o primeiro minuto senti que ela era um desses seres insubstituíveis, com uma força ativa e transcendente, que nos aconteceu como um pé-de-vento nos apanha na extensão da noite. Que carnalmente fosse ela, e tivesse um nome, e viesse trazida pela mão de outro - que tangida pelas próprias leis internas não demorasse nunca que importava tudo isto? São esses, precisamente, os seres que em qualquer sentido não demoram nunca. $\mathrm{E}$ a verdade é que encarnava para mim, de modo completo, o ser que desde há muito eu esperava. Agora que não existe mais, poderia chamá-la pelo nome, baixinho, como se pretendesse vê-la de volta, mas isto para mim não designaria a personalidade que significou, e sim a tradução humana e truncada do poder com que se projetou em nosso meio. Reduzo o tempo, anulo palavras: logo à primeira vista, com esse faro especial de que são dotadas certas vítimas, os Meneses souberam que se achavam diante de uma espécie de anjo exterminador.

Do livro de memórias de Timóteo (I) Crônica da casa assassinada. Lúcio Cardoso 


\section{crédito das imagoens}

Página 464. Adriana Varejão (1964-). Elegia mineira (tríptico). 3 fotos de 25 x 16,6 cm cada (edição de $10+3$ P.A.), 2007. Fotografia de Vicente de Mello. Acervo Ateliê Adriana Varejão. Sobre a composição do tríptico, a artista conta: "Fiz essa obra durante o tempo que morava em Minas Gerais. Tinha acabado de ler o maravilhoso livro do Lúcio Cardoso, Crônica da casa assassinada, que fala da história de uma família em uma fazenda, onde a casa é como se fosse um grande organismo vivo. Esse trabalho fala da memória, da intimidade, das entranhas descobertas, das testemunhas silenciosas. Como se costuma dizer, as paredes têm ouvidos".

Página 468. Lúcio Cardoso e William Faulkner. Autoria desconhecida (1954). Acervo Luiz Carlos Lacerda. Faulkner chegou no Brasil no dia 8 de agosto de 1954, para participar do I Congresso Internacional de Escritores, realizado em São Paulo. Em 1960, Lúcio assim relembrou em seus Diários o encontro com o escritor (com quem pode conversar brevemente em francês e fazer uma pergunta durante uma entrevista coletiva): “[...] era um pequeno homem intranquilo, desajustado, incerto, rodeado pelas luzes e curiosidade de todos os jornalistas de São Paulo que se comprimiam em torno dele. [...] Repito: um ser miúdo, malvestido e até mesmo com aparência de maltratado - mas desprendia-se dele, como facho inquieto, essa aura de força e violência que é a característica de certos homens de poder excepcional. [...] Assim eu o vi: exatamente um homem sem paz, ele, que para mim era o maior romancista vivo. [...] A falta de paz de Faulkner vinha da permanente consciência de sua condição de escritor e de ser humano crucificado à febre agônica de seu tempo". (Diários, 2012, p. 486-487). A imagem foi reproduzida no livro Contos da ilha e do continente, organizado por Valéria Lamego.

Página 472. Lúcio Cardoso (1912-1968). Sem título, óleo sobre tela, [inserir dimensões]. Assinada no c.i.e., s/d. Coleção Walmir Ayala. A pintura foi reproduzida com o nome de "Serra do Brilhante" na edição do dia 5 de outubro de 1968 da revista O Cruzeiro, publicada poucos dias após o falecimento de Lúcio. Foi reproduzida na obra $O$ Brasil por seus artistas, de Walmir Ayala (Nórdica, 1980); e parcialmente utilizada na capa do Teatro reunido. Lúcio Cardoso (Ed. UFPR, 2006), com o nome de "Montanhas de Minas". Atualmente, o quadro faz parte do acervo de André Seffrin que nos conta que Walmir Ayala se referia ao quadro como "O viajante", em uma possível referência ao pai de Lúcio.

Página 474. Lúcio Cardoso com a mão no rosto [década de 1960]. Acervo da família.

Página 479. Lúcio Cardoso com praia de Ipanema ao fundo [década de 1930]. Fotografia de Martim Gonçalves. A imagem, gentilmente cedida pela atriz, pesquisadora e professora Jussilene Santana, faz parte do acervo do Instituto Martim Gonçalves [Eros Martins Gonçalves Pereira 1919-1973[, diretor de teatro e 


\section{opiniães}

cenógrafo. $\mathrm{O}$ acervo reúne mais de 20 mil itens em sua coleção. https://institutomartimgoncalves.com.br/

Página 482. Lúcio Cardoso e amigos no bar Amarelinho, no Rio de Janeiro. Autoria desconhecida, s/d. [década de 1950]. Acervo da família. A imagem foi reproduzida no livro Contos da ilha e do continente, organizado por Valéria Lamego, que gentilmente nos encaminhou a fotografia.

Página 498. Dois stills do filme A mulher de longe. Acervo Luiz Carlos Lacerda. Por problemas financeiros, as filmagens de $A$ mulher de longe, dirigido por Lúcio Cardoso, foram interrompidas e o filme não chegou a ser concluído. No centenário do escritor, comemorado em 2012, o cineasta Luiz Carlos Lacerda lançou o documentário homônimo, que mostra o processo de recuperação dos takes originais do filme, descobertos no acervo da Cinemateca Brasileira.

Página 500. Lúcio Cardoso no Bar Veloso. Autoria desconhecida, s/d. [década de 1950]. Acervo da família. A imagem foi reproduzida no livro Contos da ilha e do continente, organizado por Valéria Lamego, que gentilmente nos encaminhou a fotografia.

Página 505. Lúcio Cardoso na juventude. Acervo da família. Autoria desconhecida, s/d [década de 1930]. A imagem foi reproduzida no livro Contos da ilha e do continente, organizado por Valéria Lamego e gentilmente compartilhada por Ésio Macedo Ribeiro.

Página 507. Lúcio Cardoso e Vito Pentagna. Acervo Luiz Carlos Lacerda. Autoria desconhecida, s/d. Vito era amigo de longa data de Lúcio, que lhe dedicou a Crônica da casa assassinada. Luiz Carlos Lacerda conta que algumas páginas da Crônica foram escritas durante as visitas que Lúcio fazia à fazendo de Vito, situada na cidade de Valença (RJ). A imagem foi reproduzida no livro Contos da ilha e do continente, organizado por Valéria Lamego.

Página 511. Lúcio Cardoso (1912-1968). Músicos, pastel sobre papel, 60 x $90 \mathrm{~cm}$. Assinado no c.i.e., s/d [1966]. Coleção Ésio Macedo Ribeiro.

Página 517. Lúcio Cardoso (1912-1968). Sem título [Mulher com mão no rosto], pastel sobre papel. Assinado no c.i.d. (1958). Acervo particular. Imagem gentilmente cedida por Andrea Vilela.

Página 519. Lúcio Cardoso em vernissage de Darel Valença Lins. Fotografia de Raul Penedo para A Noite [década de 1960]. Acervo particular. A primeira edição da Crônica da casa assassinada teve uma ilustração de Darel como imagem de capa. Imagem gentilmente cedida por Andrea Vilela. 
Página 523. Lúcio Cardoso. Fotografia de Jayme Acioli [1958]. Acervo particular. Imagem gentilmente cedida por Andrea Vilela.

Página 525. Lúcio Cardoso (1912-1968). Figuras, técnica mista sobre papel, $45 \mathrm{x}$ $30,5 \mathrm{~cm}$. Sem assinatura, s/d. Coleção Ésio Macedo Ribeiro.

Página 528. Lúcio Cardoso (1912-1968). Café. Assinado no c.i.d. [1946]. Acervo particular. O desenho foi publicado no dia 29 de dezembro de 1946 na coluna "Os arquivos implacáveis", do jornalista João Condé, no suplemento Letras e Artes do jornal $A$ manhã. A imagem foi reproduzida no livro Contos da ilha e do continente, organizado por Valéria Lamego.

As imagens presentes nesta edição estão sujeitas a direitos autorais. As fotografias do autor e pinturas, gentilmente cedidas, não podem ser reproduzidas sem anuência da família ou dos detentores dos arquivos. Os editores e a comissão editorial agradecem a Rafael Cardoso, Andrea Vilela, Luiz Carlos Lacerda, Ésio Macedo Ribeiro, Valéria Lamego, André Seffrin e Adriana Varejão a autorização para a reprodução das imagens na Opiniães. 